\title{
Banking liberalization and firms' debt structure: International evidence
}

\begin{abstract}
This paper analyzes the effect of banking liberalization on debt structure in a sample of firms in 37 developed and developing countries. Banking liberalization increases on average debt availability and reduces its maturity. Debt availability increases in countries with stronger supervision and lower protection of creditor and property rights. The reduction in debt maturity is greater in developed countries. The effect of banking liberalization also varies across firm size. Small firms in developed countries and large firms in developing countries benefit least from banking liberalization.
\end{abstract}

Keywords: debt structure, banking liberalization, supervision, investor protection, development.

JEL classification: G18, G32. 


\section{Banking liberalization and firms' debt structure: International evidence}

\section{Introduction}

The progressive liberalization of financial activity over the last two decades has attracted the attention of the financial literature. Its advocates emphasize the positive effects it has on economic growth by increasing credit availability and improving investment allocation (Bekaert et al., 2005; Galindo et al., 2007; Gehringer, 2013). Its opponents highlight that financial liberalization increases risks and, therefore, financial fragility (Kaminsky and Reinhart, 1999). The current financial crisis makes it especially relevant to gain a better understanding of the benefits and costs associated with financial liberalization. This paper offers new empirical evidence on the potential benefits of banking liberalization on the credit channel. We focus on how banking liberalization modifies firms' debt structure (availability and maturity) and on how bank supervision, investor protection, and firm size shape the influence of banking liberalization and give rise to differences between developed and developing countries.

The theoretical and empirical literature on financial liberalization does not provide unambiguous predictions and results. The empirical evidence, moreover, has focused on different aspects of financial liberalization in developing countries. ${ }^{1}$ Empirical literature focus on developing countries because financial liberalization can help develop the domestic financial system in these countries and facilitate the access of firms to mature financial markets. These benefits would be lower in developed countries (Schmukler and Vesperoni, 2006).

\footnotetext{
1 Basically, there have been three aspects of financial liberalization that have attracted interest: the effects of capital account openness (see Eichengreen, 2001 for a survey), equity market liberalization (see, for example, Bekaert et al., 2001, 2005, 2006), and banking liberalization (Laeven, 2003).
} 
However, there are also theoretical reasons for expecting a more negative effect of banking liberalization in developing countries and different effects on long and short-term debt. The literature on banking competition suggests that the influence of banking liberalization on firms' access to credit through changes in market competition critically depends on the relevance of informational asymmetries. In perfect credit markets, higher competition increases the amount of credit and reduces its cost (Klein, 1971). However, models that incorporate asymmetric information between lenders and borrowers show that increases in credit market competition reduce lending (Petersen and Rajan, 1994, 1995). This is because, in markets with asymmetric information, increased competition reduces the benefits for banks of holding close lending relationships with their borrowers so reduces the ability of relationship banking to facilitate firms' access to debt.

The Law and Finance literature provides substantial empirical evidence indicating that financial development helps firms to grow faster by supplying more external funds and that a country's financial development is related to its legal and institutional framework (La Porta et al. 1997, 1998; Levine 1997; Rajan and Zingales, 1998). Poor institutions and information disclosure characterize developing countries and may increase the intensity of information asymmetries (Levine et al., 2000; Claessens and Laeven, 2003). The presence of higher informational asymmetries in developing countries may mean that banking liberalization has more negative consequences on credit access for these countries because lending relationships are destroyed. Moreover, the literature on capital structure suggests that informational asymmetries are more relevant in long-term than in short-term debt and in small than in large firms (Rajan and Zingales, 1995; Fama and French, 2002; Frank and Goyal, 2003; Gaud et al., 2005; Flannery and Rangan, 2006).

Combining the above three strands of literature, we analyze if banking liberalization affects short and long-term debt differently, and how countries' supervision, 
investor protection, and firm size motivate different effects between developed and developing countries. We use an international panel database of a maximum of 9,822 firms in 37 developing and developed countries over the 1995-2004 period.

Our paper makes several contributions. First, we analyze the effect of banking liberalization not only on debt availability but also on its maturity. As problems of moral hazard and adverse selection are specially relevant in long-term debt, we can expect a more negative or less positive impact of banking liberalization on longterm debt. Schmukler and Vesperoni (2006) have analyzed effects both on debt availability and maturity. However, they analyze seven emerging countries and use measures of stock market liberalization and financial globalization but do not focus on banking liberalization.

Second, we analyze the interaction of banking liberalization with official and private bank supervision, and with investor protection in a country. International institutions, such as the Bank for International Settlements, the International Monetary Fund, and the World Bank, are encouraging countries to strengthen both official and private bank supervision. These recommendations are frequently discussed in the context of increasing bank stability but, as far as we know, there are no studies analyzing the effects of the interaction between banking liberalization and supervisory policy on the credit supply.

The literature on firms' capital structure has used international databases to analyze the influence of investor protection and institutions. Empirical studies show that better protection of creditors increases both the availability and maturity of firms' debt by reducing the adverse selection and moral hazard problems of debt (Demirgüç-Kunt and Maksimovic, 1999; Levine, 1999; Giannetti, 2003; Antoniou et al., 2008; Bae and Goyal, 2009). Stronger protection of property rights, however, favors increased use of equity over debt (González and González, 2008; Jiraporn et al., 2012). As equity is subject to more problems of adverse selection and moral 
hazard than debt, better protection of rights encourages the issue of equity and is, therefore, negatively related to firm leverage. To our knowledge, previous papers do not analyze how the protection of property and creditor rights modifies the effects of banking liberalization on firms' debt structure and explains potential differences between developed and developing countries.

Third, we analyze if banking liberalization affects small and large firms differently depending on countries' development. If informational asymmetries are relevant for explaining the effects of banking liberalization on firms' debt structure, the greater informational asymmetries in small firms may lead to different results depending on firm size. Empirical evidence reports mixed results depending on countries' development. Laeven (2003) finds, in firms from 13 developing countries, that financial liberalization relaxes external financing constraints for small firms but increases them for large firms. Petersen and Rajan (1994, 1995) and Zarutskie (2006) suggest the opposite for US firms. They find that more competition among creditors damages availability of debt for small and young firms. We use our international database of developed and developing countries to analyze if countries' development shapes the differential effect of banking liberalization between small and large firms.

Finally, we account for dynamic processes in firm leverage using the generalizedmethod-of-moments (GMM) estimators developed by Arellano and Bond (1991) for dynamic panel data. GMM models are designed to handle autoregressive properties in the dependent variable (firm leverage) and control for the endogeneity of the explanatory variables and unobserved firm-specific characteristics. We also include country, industry, and time dummies to prevent the coefficients of supervisory and institutional variables from being biased by incorporating confusing effects of other omitted country variables. Galindo et al. (2007) use the GMM method to analyze the effect of financial liberalization on investment efficiency but, to our knowledge, this has not been used to analyze the effect on the credit channel. 
In a closely related paper, Agca et al. (2008) assess the impact of both financial globalization and credit market deregulation on corporate leverage. They examine data from a large panel of publicly-traded non-financial firms in 38 countries over the period 1994-2002 and find that credit market globalization results in higher leverage, particularly in emerging markets. In contrast, they find that deregulation in domestic credit markets brings about a decline in leverage in emerging market firms and, to a smaller degree, an increase in leverage in advanced country firms. However, they do not analyze effects on debt maturity or how firm size, bank supervision or the protection of property and creditor rights shape the influence of banking liberalization across countries. Nor do they control for the partial adjustment process of firm leverage, unobserved firm effects, or the potential endogeneity of bank explanatory variables.

Our results for a maximum of 9,822 firms in 37 countries indicate that on average banking liberalization increases firm leverage and reduces its maturity. However, these effects vary across firms and countries. The increase in debt availability is higher in countries with stronger official and private supervision, and lower protection of creditor and property rights. We find that banking liberalization reduces debt maturity more in developed countries. Moreover, we find that the effect of banking liberalization also depends on firm size. Larger firms in developing and smaller firms in developed countries benefit the least from banking liberalization.

The rest of the paper is organized as follows. Section 2 discusses the influence of banking liberalization on debt structure and the hypotheses tested in the paper. Section 3 describes the database, methodology, and main variables used in the paper. Section 4 discusses the empirical results. Finally, Section 5 concludes.

\section{Theoretical background and hypotheses}


The potential effects of banking liberalization have traditionally been associated with changes in bank market competition. Claessens and Laeven (2004) find in a sample of 50 countries that more strictly regulated bank markets are less competitive. Theoretically, the influence of greater bank competition on firms' credit access depends on the intensity of information asymmetries. In a market without information asymmetries, an increase in competition would result in a lower price for credit and more credit availability (Klein, 1971). In markets with asymmetric information, however, an increase in banking competition may diminish banks' incentives to invest in the acquisition of soft information by establishing close relationships with borrowers. Petersen and Rajan (1995), for instance, show that credit market competition imposes constraints on the ability of firms and creditors to intertemporally share surplus. Banks in less competitive markets may, however, lend with the expectation that they will recover the initial subsidy via higher interest rates in the future. As information asymmetries are higher in long-term than in short-term debt, lending relationships would be more valuable for long-term debt in less competitive markets.

We therefore expect banking liberalization to have a different impact on short-term debt than on long-term debt. The lower informational asymmetries of short-term debt suggest that banking liberalization would bring down prices and make larger amounts of short-term debt available to firms. Moreover, greater competition that reduces bank charter value increases bank risk-taking incentives (Keeley, 1990) so is likely to encourage banks to finance new investments that they would not consider if they were behaving more cautiously. Both effects lead us to forecast greater availability of short-term debt for firms.

The greater information asymmetries of long-term debt, however, lead to a less clear expansionary effect for banking liberalization on debt maturity. Banking liberalization may limit the interest rates that banks can charge in the future and prevent higher interest rates in the future from subsidizing lower interest rates in 
the present. It basically reduces the ability to contract long-term debt. As the predicted positive impact on short-term debt is greater than for long-term debt, we can expect a reduction in firms' debt maturity. Therefore, the impact of banking liberalization on debt availability will depend on whether or not the positive effect on short-term debt offsets the potential negative effect on long-term debt. Following the above arguments, our first hypothesis is:

H1: Banking liberalization has a more positive (less negative) effect on firms' short-term debt than on long-term debt.

The effect of banking liberalization on firms' debt structure may also vary across countries depending on bank supervision and investor protection. If bank supervision affects the enforcement of bank regulation, we would expect greater effects from changes in bank regulation as private and official bank supervision becomes stronger. If a country's bank supervision is weak, we would expect regulation to be less binding for banks and to reduce the potential impact of changes in banking regulations on firms' debt structure. Although official supervision is specifically designed to enforce bank regulation, since Basel II, banking authorities have been aiming to reinforce both official and private supervision. For this reason, we include both types of supervision in the empirical analysis. Our second hypothesis is:

H2: The influence of banking liberalization on debt structure is positively related to bank supervision in a country.

The Law and Finance literature has highlighted the importance of creditor rights for increasing both the availability and the maturity of debt for firms (Levine, 1999; Giannetti, 2003; González and González, 2008; Antoniou et al., 2008) while better protection of property rights and corporate governance favor equity issues (González and González, 2008; Jiraporn et al., 2012). It is less clear, however, how investor protection complements or substitutes the effect of banking 
liberalization on firms' debt structure. On the one hand, if better protection of creditor rights makes debt more available, we might expect banking liberalization to have lower marginal benefits on debt availability and maturity. In this case, the protection of creditor rights and bank liberalization would be substitutes. On the other hand, banking liberalization cannot by itself facilitate bank loans to firms if regulation does not adequately protect creditor rights. In this case, better protection of creditor rights would complement banking liberalization to facilitate firms' access to bank debt.

Similarly, if better protection of property rights favors the use of equity versus debt, we might expect banking liberalization to have lower positive (higher negative) effects on debt in these environments. Protection of property rights and banking liberalization would then be substitutes. Better protection of property rights, however, might complement banking liberalization and increase (decrease) its positive (negative) effect on debt structure. Bae and Goyal (2010) show that corporate governance affects firms' profits when countries liberalize their equity markets. Their results reveal that better-governed Korean firms experience higher abnormal returns, have more foreign ownership, and exhibit higher rates of physical capital accumulation following equity liberalization. As both types of relation are theoretically possible, we make no a priori forecast as to whether banking liberalization complements or substitutes the protection of creditor and property rights, and we treat it as an empirical issue.

The influence of countries' investor protection on the effects of bank liberalization on firms' debt structure may differ between developed and developing countries. The Law and Finance literature suggests this link by stating that a country's legal and institutional framework explains its financial and economic development (La Porta et al. 1997, 1998; Levine 1997; Rajan and Zingales, 1998). Poorer investor protection in developing countries would increase the relevance of information asymmetries in such countries and lead to more negative (less positive) 
consequences for banking liberalization on firms' debt structure. So, our third hypothesis is:

H3: The influence of banking liberalization on debt structure is less positive (more negative) in developing countries.

The influence of information asymmetries on the effects of banking liberalization may also differ between small and large firms. Small firms are characterized by larger informational asymmetries (Rajan and Zingales, 1995; Fama and French, 2002; Frank and Goyal, 2003; Gaud et al., 2005; Flannery and Rangan, 2006) and greater dependence on bank financing for their investments. Large firms, on the contrary, have better access to domestic and international markets and are usually less dependent on domestic bank markets. So, the impact of banking liberalization on debt structure would be less positive or more negative in small firms.

However, the effect of banking liberalization on debt structure according to firm size might be influenced by the country's economic development. Petersen and Rajan (1994, 1995), Laeven (2003) and Zarutskie (2006) provide evidence on this. On the one hand, Petersen and Rajan (1994, 1995) and Zarutskie (2006), using data from US firms, find that more competition among creditors damages availability of debt for small and young firms. This suggests that more competition discourages creditors from lending to firms whose qualities are not well known and is consistent with the previously forecasted influence of firm size on the effect of banking liberalization on debt structure. On the other hand, Laeven (2003) finds the opposite result for a sample of firms from 13 developing countries. He shows that financial liberalization relaxes external financing constraints for small firms, but increases them for large ones. Because of these differences in the results, we analyze the interaction between country's economic development and firm size. Our fourth hypothesis is: 
H4: Firm size increases (reduces) the positive (negative) effect of banking liberalization on firms' debt structure in developed countries.

\section{Database, methodology, and variables}

\subsection{Database}

Firm data comes from the Worldscope database which contains financial statement data and stock prices from many countries in comparable form. We initially selected the 49 countries considered by La Porta et al. (1998) over the 1995-2004 period, but eliminated 12 of them because of scarce data: Colombia, Ecuador, Egypt, Israel, Jordan, Kenya, Nigeria, Sri Lanka, Taiwan, Uruguay, Venezuela, and Zimbabwe. The final number of countries considered is therefore 37, including both developed and developing countries.

We excluded firms whose capital decisions may reflect special factors: the financial industry (SIC codes 6000 - 6999) and regulated enterprises (SIC codes 4000 4999). Since we apply the GMM first-difference estimator with at least one lag of the dependent variable and two lags of the proxy for banking liberalization, firms without sufficient consecutive years were excluded. The final sample includes a maximum of 9,822 firms with 41,262 firm-year observations.

\subsection{Methodology}

We adopt the traditional dynamic model of capital structure. The model tests whether there is a leverage target and, if so, how quickly a firm moves toward the target. The form of the target adjustment model states that changes in the debt ratio $\left(D_{i t}-D_{i t-1}\right)$ partially absorb the difference between the target leverage $\left(D_{i t} *\right)$ and lagged leverage ( $\left.D_{\text {it-1 }}\right)$ :

$\left(D_{i t}-D_{i t-1}\right)=\alpha\left(D_{i t}^{*}-D_{i t-1}\right)$ 
where $\alpha$ measures the transaction costs that prevent complete adjustment to the target leverage. It varies between 0 and 1 and is inversely related to adjustment costs.

As the target debt is unobservable, we model it as a linear function of the traditional determinants of capital structure as indicated by Rajan and Zingales (1995), i.e., profitability (PROF), growth opportunities (GROWTH), tangible assets (PPE), and size (SIZE). ${ }^{2}$ Substituting these variables for $\mathrm{D}^{*}$ in model [1], we get:

$D_{i t}=\alpha a_{0}+(1-\alpha) D_{i t-1}+\alpha a_{1} P_{R O F_{i t}}+\alpha a_{2}$ GROWTH $_{i t}+\alpha a_{3} P P E_{i t}+\alpha a_{4} \operatorname{SIZE}_{i t}$

As we used an international database, we incorporate country variables and the influence of banking liberalization. As estimations are carried out with panel data, our basic model is:

$D_{i j k t}=\alpha a_{0}+(1-\alpha) D_{i j k t-1}+\alpha a_{1} P R O F_{i j k t}+\alpha a_{2} G R O W T H_{i j k t}+\alpha a_{3} P P E_{j k i t}+\alpha a_{4} S_{I Z E_{i j k t}}+$ $+b_{5}$ PRBOND $_{k t}+b_{6}$ CONC $_{k t}+b_{7}$ RIGHTS $_{t} x$ ENFORCE $_{k t}+b_{8}$ CREDITORS $_{t} x$ ENFORCE $_{k t}$ $+b_{9} \sum_{\mathrm{m}=0}^{2} B F R E E D O M_{k t-m}+\theta_{\mathrm{kj}}+\lambda_{\mathrm{jt}}+\varphi_{\mathrm{kt}}+\mu_{\mathrm{j} \mathrm{jk}}+\varepsilon_{\mathrm{j} \mathrm{jkt}}$

Where $i, j, k$, and t denote firm, industry, country, and year, respectively. The main variable in our study is BFREEDOM. It is a proxy for banking liberalization in country $\mathrm{k}$ in year $\mathrm{t}$. We include the current value and two lags of BFREEDOM to capture potential effects of banking liberalization over the long run.

We include as a control variable the development of the corporate bond market as a percentage of private domestic debt over GDP (PRBOND). This variable controls for potential substitution effects between bank debt and corporate bonds. In

\footnotetext{
${ }^{2}$ Booth et al. (2001) and Delcoure (2007) also support the importance of these variables in explaining the capital structure of firms in developing countries.
} 
countries where the corporate bond market is sufficiently developed, firms might substitute corporate bonds for bank loans and positively bias the estimated coefficients for banking liberalization.

As additional control variables at country level we include three country characteristics previously incorporated in studies on firms' capital structure with international data: bank market concentration (CONC), protection of property rights (RIGHTS), and protection of creditor rights (CREDITORS). As effective protection of rights requires both explicit legal protection and enforcement of the law, we interact RIGHTS and CREDITORS with a variable capturing law enforcement in countries (ENFORCE).

Bank market concentration has usually been used as a proxy for bank market competition. As effects of banking liberalization may potentially be associated with changes in bank competition, we check if the influence of banking liberalization remains after controlling for bank concentration. We do not forecast a clear sign for $b_{6}$ as the banking literature suggests a negative effect on firm leverage in perfect capital markets but a positive one in markets with asymmetric information (Petersen and Rajan, 1994, 1995).

The protection of property rights is crucial to solve problems of adverse selection and moral hazard in financial contracts (La Porta et al., 1997, 1998). As equity issue is subject to more of these problems than debt, empirical evidence confirms that stronger protection of property rights favors increased use of equity over debt (González and González, 2008; Jiraporn et al., 2012). We therefore expect a negative sign for the coefficient of RIGHTSXENFORCE $\left(b_{7}\right)$.

The literature on firms' capital structure has found a positive relation between the protection of creditor rights and firms' leverage, which is greater with long-term debt (Demirgüç-Kunt and Maksimovic, 1999; Giannetti, 2003; Qian and Strahan, 2007; González and González, 2008). We therefore include the interaction between 
CREDITORS and ENFORCE as a control variable and expect a positive sign for this coefficient $\left(b_{8}\right)$.

We include four specific effects: country-industry, industry-year, country-year, and firm-specific effects. The four sets of specific effects should control for most shocks affecting firm leverage. $\theta_{k j}$ is a country-industry specific effect to control not only for characteristics that are specific to either an industry or a country, but also for characteristics that are specific to an industry located in a particular country, as long as these are persistent over time. These include, for instance, the effect of persistent differences in size, concentration, financial frictions, external dependence, or government intervention and support, derived from different factor endowments, market size, or institutional characteristics that may generate different debt ratios across industries and countries. $\lambda_{j t}$ is an industry-year specific effect to control for worldwide industry shocks. $\varphi_{k t}$ is a country-year specific effect. It includes, for instance, the development of financial markets and bank credit, or aggregate country-specific shocks. This approach has the advantage that it is less likely to suffer from omitted variable bias or model specification than traditional regressions. Dell' Ariccia et al. (2008) have previously used this approach to analyze the real effects of a banking crisis in an international sample of banks. Finally, $\varepsilon_{\mathrm{ijkt}}$ is the error term.

We extend the basic model to analyze how the influence of banking liberalization varies across countries depending on bank supervision, investor protection, and economic development. We include an interaction term between banking freedom and each country variable ( $\Sigma$ BFREEDOM $x$ COUNTRYVAR). The inclusion of dummy country variables avoids the need for these supervisory and institutional country variables to enter the regression on their own and allows us to focus on the terms of their interaction with banking freedom. 


$$
\begin{aligned}
& D_{i t}=\alpha a_{0}+(1-\alpha) D_{i t-1}+\alpha a_{1} P R O F_{i t}+\alpha a_{2} G R O W T H_{i t}+\alpha a_{3} P P E_{i t}+\alpha a_{4} S I Z E_{i t}+ \\
& +b_{5} \text { PRBOND }_{k t}+b_{6} \text { CONC }_{k t}+b_{7} \text { RIGHTS }_{t} x \text { ENFORCE }_{k t}+b_{8} \text { CREDITORSt } x \text { ENFORCE }_{k t} \\
& +b_{9} \sum_{\mathrm{m}=0}^{2} \text { BFREEDOM }_{k t-m}+b_{10} \sum_{\mathrm{m}=0}^{2} \text { BFREEDOM }_{k t-m} \mathrm{x} \text { COUNTRYVAR } R_{t}+ \\
& +\theta_{\mathrm{kj}}+\lambda_{\mathrm{jt}}+\varphi_{\mathrm{kt}}++\mu_{\mathrm{ijk}}+\varepsilon_{\mathrm{ijkt}}
\end{aligned}
$$

As country variables interacting with banking freedom we include official supervision (OFFICIAL), private supervision (MONITOR), protection of property (RIGHTS) and creditor (CREDITORS) rights, and economic development (DEV) in a country.

We apply generalized-method-of-moments (GMM) estimators developed for dynamic models of panel data by Arellano and Bond (1991). This methodology is specifically designed to address three particular econometric issues: (i) the presence of unobserved firm-specific effects, eliminated by taking first differences of the variables; (ii) the autoregressive process in the data regarding leverage ratio behavior (i.e., the need to use a lagged-dependent-variables model to capture the dynamic nature of the capital structure decisions); and (iii) the likely endogeneity of the explanatory variables. We control for the potential endogeneity of PROF, GROWTH, PPE, and SIZE in the GMM estimations by using two- to four-period lags of the same variables as instruments. The country variables (PRBOND, CONC, RIGHTS, CREDITORS, and ENFORCE) and country-industry, industry-year, and country-year dummy variables are considered exogenous.

We use two-step estimation and specify the robust estimator of the variancecovariance matrix of the parameters. We report results using one lag when the dependent variable is total debt and two lags when the dependent variable is short or long-term debt. The use of two lags for short and long-term debt is derived from statistical significance for short-term debt. The validity of the GMM estimator approach rests on two testable assumptions. First, for the instruments to be valid, they need to be uncorrelated with the error term. We use the Sargan Test of over- 
identifying restrictions to test this assumption (where statistically non-significant values confirm the validity of the instruments). Second, the GMM estimator requires the absence of second-order serial correlation in the first difference residual. We employ the $m_{2}$ statistic developed by Arellano and Bond (1991) to test for a lack of second-order serial correlation in the first-difference residual. An insignificant $m_{2}$ statistic indicates that the model is correctly specified.

\subsection{Variables}

Appendix A describes how we define the variables used in the empirical analysis and their sources. Most of the variables are self-explanatory and have been used in other cross-country studies of firms' debt structure. We therefore only describe in greater detail the proxies for our main variables: debt structure and banking liberalization.

\subsubsection{Debt structure}

We use three proxies to measure firms' debt structure: 1) Total debt is measured by the ratio between long-term and short-term debt and the market value of assets, 2) Long-term debt is measured by the ratio between long-term debt and the market value of assets and, 3) Short-term debt is measured by the ratio between short-term debt and the market value of assets. Market value of assets is defined as total assets minus book value of equity plus market value of equity. ${ }^{3}$ The first variable measures the availability of debt whereas the other two variables are proxies for debt maturity.

Table 1 shows for the total sample a mean leverage ratio of $26.30 \%$, a mean longterm debt ratio of $12.82 \%$, and a mean short-term debt ratio of $11.17 \%$ with an

\footnotetext{
${ }^{3}$ Welch (2004) argues that we should use market leverage ratios since our theories of target ratios are implicitly about market leverage ratios. Many other researchers analyze market value debt ratios, such as Fama and French (2002), Leary and Roberts (2005), and Flannery and Rangan (2006).
} 
average profitability of $9.28 \%$ and a mean value for growth opportunities of 2.97 . The companies in the sample have on average a $32.17 \%$ ratio of property, plant, and equipment to total assets.

\section{INSERT TABLE 1 ABOUT HERE}

\subsubsection{Banking liberalization}

We measure banking liberalization using the index of Financial Freedom published annually for each country by the Heritage Foundation. It is a composite index for the extent of government regulation of financial services; the extent of state intervention in banks and other financial services; the difficulty of opening and operating financial services firms (for both domestic and foreign individuals); and government influence on the allocation of credit. It varies on a scale of 0 to 100 . Higher values indicate a less restrictive banking system. A detailed explanation of the specific banking and finance grading scale is given in Appendix B.

\section{INSERT TABLE 2 ABOUT HERE}

Table 2 shows that there are important differences in the value of BANKING FREEDOM among countries. The countries with the most open banking system are Australia, Netherlands, New Zealand, and UK (their mean value is 90) while the country with the least banking freedom is India (its mean value is 30 ). The mean value of BFREEDOM is 65.21 (Table 1 ). Figure 1 shows the evolution of banking liberalization over the 1995-2004 period depending on countries' development. It reveals that banking freedom has increased slightly in the countries in our sample, although evolution of the index is different between developed and developing countries. Developed countries have greater levels of financial freedom than developing countries (a mean value of 69.88 in developed versus 49.73 in developing countries), and the difference has increased over the 1995-2004 period. The difference between the mean-country values of the index of economic freedom has increased from 12.21 points (65.29 in developed vs 53.08 in developing 
countries) in 1995 to 20.83 points (70.83 in developed vs. 50 in developing countries) in 2004.

\section{INSERT FIGURE 1 ABOUT HERE}

\section{Results}

\subsection{Banking liberalization and firm leverage}

Table 3 shows the results of the partial-adjustment model [3] for the whole sample of firms using as dependent variables total, short-term, and long-term debt. The coefficients of country-industry, industry-year, and country-year dummies are not reported to save space. The $m_{2}$ statistic allows us to reject the null hypothesis of the absence of second-order serial correlation in the first-difference residuals. The statistically non-significant values for the Sargan test of over-identifying restrictions confirm the validity of the instruments in all estimations.

The positive and statistically significant coefficients of BFREEDOM and BFREEDOMt-1 in column (1) indicate that the openness of the country's banking system has a positive influence on total debt. This result holds in column (2) when we explicitly control for bank concentration, the protection of property and creditor rights, and law enforcement in a country. The results also show some degree of delay for the effect of banking liberalization since coefficients for some of the lagged values of BFREEDOM are statistically significant.

Banking liberalization also affects firms' debt maturity. Columns (3) and (4) report positive and statistically significant coefficients for BFREEDOM when the dependent variable is the short-term debt ratio, whereas the coefficients of BFREEDOM and its two lags are non-significant when we use the long-term debt ratio as the dependent variable in columns (5) and (6). The change in results depending on debt maturity indicates that, although banking liberalization increases the total amount of debt available to firms, it basically increases average short-term debt, and has no effect 
on long-term debt. This result is consistent with our hypothesis 1 , indicating that banking liberalization might reduce the benefits for banks of close lending relationships that allow reduction of the higher adverse selection and moral hazard problems associated with long-term debt. However, banking liberalization increases the availability of short-term debt, for which informational asymmetries between borrowers and lenders are less relevant and close lending relationship are less beneficial. The net effect is an increase in debt availability for firms (a higher total debt ratio) and a reduction in debt maturity.

In economic terms, using for instance the coefficients in column (2) of Table 2, a standard deviation increase in banking liberalization (19.37) would cause an increase in the total debt available which represents 14.09 per cent of its mean value. This effect represents an increase of 12.29 per cent in the mean value of short-term debt when we use the coefficients in column (4).

\section{INSERT TABLE 3 ABOUT HERE}

The coefficients of the control variables are consistent with those found in previous studies. The positive and statistically significant coefficients of $D E B T_{t-1}$ in all estimations suggest that firms have a target leverage to which they partially adjust in each period. Coefficients of DEBT $\mathrm{t}_{-1}$ for total debt take values of around 0.71 , which implies $\alpha$ values of approximately 0.29 . This value is similar to those reported by Huang and Ritter (2009), where the publicly traded US firms converge toward their long-run target at a rate of $23.2 \%$ per year. We also obtain statistically significant coefficients for the two lags of the short-term debt in columns (3)-(4) and for one lag of the long-term debt in columns (5) and (6).

The coefficients of asset tangibility are positive and statistically significant in all estimations. They are consistent with the traditional arguments of the trade-off theory and the usefulness of a greater value of tangible assets as collateral to reduce agency cost between firms and debtholders. Size also has a positive and 
significant impact on firms' debt, which is consistent with size being an inverse proxy for the probability of bankruptcy. This result is similar to results shown in Rajan and Zingales (1995), Fama and French (2002), Frank and Goyal (2003), Flannery and Rangan (2006), Gaud et al. (2005), and Antoniou et al. (2008). Coefficients of profitability and growth opportunities are not statistically significant at standard levels.

The development of the corporate bond market in a country has negative coefficients in all estimations and is statistically significant in columns (2), (4), and (6). These negative coefficients suggest that changes in total debt are driven by changes in bank debt, but the development of the corporate bond market is a better proxy for financial market development and thus is positively associated with equity financing and negatively with bank or total debt.

Bank concentration has a negative influence on short-term debt and a nonsignificant influence on the long-term debt ratio. As a net result, bank concentration has a negative coefficient for total debt ratio.

The proxies for the protection of property and creditor rights have, respectively, negative and positive coefficients. Although positive, only the coefficient of CREDITORSXENFORCE in column (4) is not statistically significant at conventional levels. The negative coefficients for RIGHTSXENFORCE are consistent with better protection of property rights lowering agency costs associated with equity issues and then promoting lower firm leverage. The positive coefficients for CREDITORSXENFORCE confirm that legal protection of creditor rights can reduce the agency cost of debt, as documented by Demirguc-Kunt and Maksimovic (1999), Giannetti (2003), González and González (2008), and Antoniou et al. (2008).

\subsection{Banking liberalization, supervision, and firm leverage}

We now analyze whether the effects of banking liberalization on debt structure vary across countries depending on bank supervision. In estimations in Table 4 we 
include, sequentially, interaction terms between banking freedom and our proxies for official and private supervision. Again, the $m_{2}$ statistic and Sargan test allow us, respectively, to reject the lack of second-order serial correlation in the firstdifference residuals and to confirm the validity of the instruments in all estimations.

The negative and significant coefficients of BFREEDOMt-1 in columns (1), (4), and (7) reveal that banking liberalization reduces not only long-term debt but also short-term and total debt in countries with the lowest official supervisory powers. The interaction between banking freedom and official supervision has positive coefficients for all debt ratios (total, short-term, and long-term debt). In particular, we find positive and significant coefficients for BFREEDOMt-1 $x$ OFFICIAL both when we only analyze the interaction between banking freedom and official supervision in columns (1), (4), and (7), and when we consider simultaneously the interaction between banking freedom and private monitoring in columns (3), (6), and (9). These results indicate that official supervision reduces the negative effect that banking liberalization has on debt availability and maturity in countries with the weakest official supervision. This result is consistent with our hypothesis 2, suggesting that the stronger the bank supervision the greater (lower) the positive (negative) effect of banking liberalization on debt availability.

Private monitoring also improves the influence of banking liberalization on debt availability whatever the proxy we use for firm leverage in columns (2), (5), and (8). The negative and significant cumulative coefficient of SBFREEDOM and the positive and significant cumulative coefficient of $\Sigma$ BFREEDOM $\times$ MONITOR in column (2) suggest that the positive effect of banking liberalization on debt availability requires a minimum of private supervision and that it increases with the intensity of private supervision. Similarly, we find that positive and significant coefficients of BFREEDOM $\times$ MONITOR and BFREEDOM $\mathrm{t}_{-2} \times$ MONITOR in column (5) shape the influence of banking liberalization on short-term debt. Moreover, the negative and significant coefficient of BFREEDOMt-2 indicates that banking freedom reduces 
access by firms to short-term debt in countries with the worst private monitoring. Private monitoring also shapes the influence of banking freedom on long-term debt ratios. The negative and significant coefficient of BFREEDOMt $\mathrm{B}_{\mathrm{t}}$ in column (8) indicates that banking freedom reduces long-term debt in countries with the worst private monitoring. The positive coefficient of BFREEDOMt $\mathrm{t} \times$ MONITOR suggests that this negative effect is reduced when private monitoring in a country improves.

The influence of private monitoring to improve the effect of banking liberalization on debt availability is lower when we consider, simultaneously, private monitoring and official supervision in columns (6) and (9); it disappears altogether in column (3) when we analyze the effect on total debt. The significant coefficient of BFREEDOM $\mathrm{t}_{\mathrm{t}-1} \times$ OFFICIAL and the non-significant coefficients of the interaction of BFREEDOM or its lags with MONITOR in column (3) suggest a more positive influence for official supervision than for private supervision on firms' debt availability. The greater influence of official supervision in banking liberalization is consistent with official supervision being the main mechanism to enforce bank regulation.

\section{INSERT TABLE 4 ABOUT HERE}

\subsection{Banking liberalization, investor protection, and firm leverage}

We analyze in this section how the quality of investor protection shapes the influence of banking liberalization on firms' debt structure. The results are shown in Table 5. In the estimations we include, sequentially, the interactions between bank liberalization and our proxies for the protection of property and creditor rights in a country.

The cumulative coefficient of banking liberalization ( $\Sigma$ BFREEDOM) is positive for our three dependent variables in columns (1), (3), and (5) when we include the interaction of banking liberalization and the enforced protection of property rights. We obtain a negative sign for the cumulative coefficient of the interaction term of 
$\sum$ BFREEDOM $\times$ RIGHTS $\times$ ENFORCE when we consider the total debt ratio as the dependent variable (column (1)). This negative cumulative coefficient suggests that better enforced protection of property rights reduces the availability of firms' debt. The cumulative coefficient of this interaction term is not statistically significant in columns (3) and (5), when the dependent variable is, respectively, the short-term and long-term debt. The significant coefficients of the Sargan test in columns (3) and (4) oblige us to be cautious when interpreting the results for short-term debt.

\section{INSERT TABLE 5 ABOUT HERE}

The cumulative coefficients for $\Sigma$ BFREEDOM $\times$ CREDITORS $\times$ ENFORCE are negative and statistically significant for the three dependent variables in columns (2), (4), and (6). Moreover, the coefficients of CREDITORS $\times$ ENFORCE and the cumulative coefficients of $\Sigma$ BFREEDOM keep their positive sign in these estimations. The positive coefficients of CREDITORS $\times$ ENFORCE and BFREEDOM suggest that both variables favor firms' debt but, the higher the protection of creditors (banking liberalization), the lower the marginal benefit of increasing banking liberalization (protection of creditors). This indicates that the protection of creditor rights and banking liberalization are substitutes for promoting bank lending. The positive cumulative coefficient of BFREEDOM in column (6) indicates that banking liberalization even has a positive influence on long-term debt in countries with the lowest protection of creditor rights. One potential explanation is that weak protection of creditors does not favor lending relationships, so greater banking liberalization does not have any lending relationships to destroy and promotes better access not only to short-term debt but also to long-term debt.

In economic terms, a standard deviation increase in the protection of creditor rights (1.26) would reduce the impact of a standard deviation increase in banking liberalization on total, short-term, and long-term debt by, respectively, $22.17 \%$, $20.94 \%$, and $19.27 \%$ of the respective mean value of each type of debt. 


\subsection{Banking liberalization, development, firm size, and leverage}

We now analyze differences in the effects of banking liberalization between developed and developing countries and whether the influence of firm size varies between both groups of countries. The relevance of bank supervision and investor protection in a country for shaping the effect of banking liberalization may lead to differences between developed and developing countries.

We include in the regressions three interaction terms: $\Sigma$ BFREEDOM $\times$ DEV, $\Sigma$ BFREEDOM $\times$ SIZE, and $\Sigma$ BFREEDOM $\times$ SIZE $\times$ DEV. When all the interaction terms are included, $\Sigma$ BFREEDOM captures the influence of banking liberalization on smaller firms in developing countries, while $\Sigma$ BFREEDOM $\times$ SIZE indicates the difference in the impact of banking liberalization when firm size increases in developing countries. $\Sigma$ BFREEDOM $\times$ DEV captures the difference in the impact of banking liberalization on smaller firms between developed and developing countries, and SBFREEDOM $\times$ SIZE $\times$ DEV indicates the difference in the impact of banking liberalization between developed and developing countries when firm size increases. The results are reported in Table 6.

\section{INSERT TABLE 6 ABOUT HERE}

Columns (1), (3), and (5) report differences in the average influence of banking liberalization on firm's access to debt between developed and developing countries. The cumulative positive coefficients of BBFREEDOM in columns (1) and ( 3 ) indicate that banking liberalization increases the availability of short-term and total debt in developing countries, but we do not find a significant effect of banking freedom on long-term debt in developing countries in column (5). We only find a statistically significant cumulative coefficient for the interaction between SBFREEDOM and DEV in column (3) when the short-term debt ratio is the dependent variable. This result suggests that the positive influence of banking liberalization on short-term debt is 
higher in developed countries. So, banking liberalization increases the availability of short-term debt and reduces debt maturity more in developed countries.

We analyze potential differences in the influence of firm size between developed and developing countries in columns (2), (4), and (6). The cumulative negative coefficients of $\Sigma$ BFREEDOM $\times$ SIZE suggest that the positive effect of banking liberalization on short-term, long-term, and then total debt ratios decreases with firm size in developing countries. Moreover, the cumulative coefficient for the interaction term $\Sigma$ BFREEDOM $\times$ SIZE for long-term debt is higher than for shortterm debt. It indicates that banking liberalization not only reduces debt availability for large firms in developing countries but also has a negative effect on debt maturity for these firms.

These results are consistent with the adverse effects of financing constraints on large firms that Laeven (2003) finds for financial liberalization in firms from 13 emerging countries. He argues that large firms may have had better access to preferential direct credit before the financial liberalization.

The cumulative positive coefficients of BBFREEDOM $\times$ DEV and $\Sigma$ BFREEDOM $\times$ SIZE $x$ DEV in column (2) indicate that larger firms in developed countries are the most positively affected in access to debt when banking liberalization increases. This result is consistent with our hypothesis 4 and those found by Petersen and Rajan (1994, 1995) and Zarutskie (2006) in US firms. The model in Petersen and Rajan (1995) suggests that greater competition among creditors discourages them from lending to firms whose credit qualities are not well known, and from subsidizing such higher-risk loans by charging higher interest rates as they age. Our result suggests that relationship banking basically involves smaller firms only in developed countries, whereas in less developed countries it is the larger firms that suffer the greatest reduction in debt availability when banking liberalization increases. 
The $m_{2}$ statistic and Sargan test allow us, respectively, to again reject the lack of second-order serial correlation in the first-difference residuals and to confirm the validity of the instruments in all estimations.

\section{Conclusions}

We analyze the effect of banking liberalization on firms' debt structure using a panel database of a maximum of 9,822 firms in 37 countries over the 1995-2004 period. Our results show that, on average, banking liberalization increases firms' debt availability and reduces its maturity. We observe an increase in the total debt ratio based on an increase in the short-term debt ratio but on a non-increase in the long-term debt ratio. The different effect on short and long-term debt is consistent with the relevance of informational asymmetries for explaining the effect of banking liberalization. When the greater informational asymmetries of long-term debt increase the relevance of relationship banking for solving adverse selection and moral hazard, they reduce the benefits of banking liberalization. Short-term debt, however, is less dependent on bank relationship, and greater competition associated with banking liberalization increases its availability. These results are consistent with the model of Petersen and Rajan (1995) in which greater banking market competition reduces long-term lending to firms whose credit qualities are not well known because it prevents banks from subsidizing current higher-risk loans by charging higher interest rates in the future and from getting to know the real quality of firms.

We also find that the effects of banking liberalization vary across firms and countries. The increase in debt availability is higher in countries with stronger official and private supervision, and lower protection of creditor and property rights. The reduction of debt maturity is higher in countries with better protection of property rights and in developed countries. We also find that the effect of banking liberalization varies with firm size depending on countries' development. Larger 
firms in developing and smaller firms in developed countries benefit the least from banking liberalization.

The results have important policy implications for banking liberalization processes. The empirical results suggest caution when a banking liberalization process is adopted because, although it will increase the total debt available for firms, it will also reduce debt maturity. Although the effects are not equal across countries, we can propose some policy recommendations for banking liberalization. In particular, successful banking liberalization requires strong official or private supervision to provide positive effects for firms' debt availability. This implies that liberalization policies must go together with reinforcement of the power of authorities in countries where official supervision is less developed. Moreover, banking liberalization reduces firms' access to long-term debt, especially for larger firms in developing countries. Unlike the mixed effects of banking liberalization, better protection of creditor rights increases access to both short-term and long-term debt, so increasing such protection would be an effective way of improving the credit channel.

\section{Acknowledgements}

We thank participants at the ACEDE Conference in Barcelona (2011) for helpful comments and suggestions. Financial support from the Projects MICINN-09ECO2009-11758 and ECO2012-31772 is gratefully acknowledged. A previous version of the paper was published as working paper n⿳ 632/2011 of the Fundación de las Cajas de Ahorros (FUNCAS). 


\section{References}

Agca, S., De Nicoló, G., \& Detragiache, E. (2008). Financial reforms, globalization, and corporate borrowing: International evidence. Working paper.

Antoniou, A., Guney, Y., \& Paudyal, K. (2008). The determinants of capital structure: Capital market-oriented versus bank-oriented institutions. Journal of Financial and Quantitative Analysis, 43 (1), 59-92.

Arellano, M., \& Bond, S. (1991). Some tests of specification for panel data: Monte Carlo evidence and an application to employment equations. Review of Economic Studies, 58, 277-297.

Bae, K.H., \& Goyal, V.K. (2009). Creditor Rights, Enforcement, and Bank Loans. Journal of Finance, 64 (2), 823-860.

Bae, K.H., \& Goyal, V.K. (2010). Equity market liberalization and corporate governance. Journal of Corporate Finance, 16 (5), 609-621.

Barclay, M.J., \& Smith, C.W. (1995). The maturity structure of corporate debt. Journal of Finance, 50, 609-631.

Barth, J.R., G. Caprio Jr., \& Levine, R. (2001). The regulation and supervision of banks around the world: a new database" in Robert E. Litan and Richard Herring, Editors, Integrating emerging market countries into the global financial system, Brookings-Wharton Papers on Financial Services, Brookings Institution Press.

Bekaert, G., Harvey, C.R., \& Lundblad, C. (2001). Emerging Equity markets and economic development. Journal of Development Economics, 66, 465-504.

Bekaert, G., Harvey, C.R., \& Lundblad, C. (2005). Does financial liberalization spur growth? Journal of Financial Economics, 77, 3-55.

Bekaert, G., Harvey, C.R., \& Lundblad, C. (2006). Growth volatility and financial liberalization. Journal of International Money and Finance, 25, 370-403. 
Beck, T., Demirgüç-Kunt, A., \& Levine, R. (2009). Financial Institutions and Markets Across Countries and over Time: Data and Analysis. World Bank Policy Research Working Paper 4943. Database available at http://econ.worldbank.org.

Booth, L., Aivazian, V., Demirguc-Kunt, A., \& Maksimovic, V. (2001). Capital structure in developing countries. Journal of Finance, 56, 87-130.

Claessens, S., \& Laeven, L. (2003). Financial development, property rights, and growth. Journal of Finance, 58, 2401-2436.

Claessens, S., \& Laeven, L. (2004). What drives bank competition? Some international evidence. Journal of Money, Credit, and Banking, 36, 585-592.

Delcoure, N. (2007). The determinants of capital structure in transitional economies. International Review of Economics and Finance, 16 (3), 400-415.

Dell'Ariccia, G., Detragiache, E., \& Rajan. R. (2008). The Real Effect of Banking Crises. Journal of Financial Intermediation, 7, 89-112.

Demirgüç-Kunt, A., \& Maksimovic, V. (1999). Institutions, financial markets, and firm debt maturity. Journal of Financial Economics, 54, 295-336.

Djankov, S., McLiesh, C., \& Shleifer, A. (2007). Private credit in 129 countries. Journal of Financial Economics, 84, 299-329.

Eichengreen, B. (2001). Capital account liberalization: what do the cross-country studies tell us? World Bank Economic Review, 15 (3), 341-365.

Fama, E.F., \& French, K.R. (2002). Testing trade-off and pecking order predictions about dividends and debt. Review of Financial Studies, 15 (1), 1-33.

Flannery, M.J., \& Rangan, K.P. (2006). Partial adjustment toward target capital structures. Journal of Financial Economics, 79 (3), 469-506.

Frank, M., \& Goyal, V.K. (2003). Testing the pecking order theory of capital structure. Journal of Financial Economics, 67, 217-248.

Galindo, A., Schiantarelli, F., \& Weis, A. (2007). Does financial liberalization improve the allocation of investment?: Micro-evidence from developing countries. Journal of Development Economics, 83, (2), 562-587. 
Gaud, P., Jani, E., Hoesli, M., \& Bender, A. (2005). The capital structure of Swiss companies: An empirical analysis using dynamic panel data. European Financial Management, $11(1), 51-69$.

Gehringer, A. (2013). Growth, productivity and capital accumulation: The effects of financial liberalization in the case of European integration. International Review of Economics and Finance, 25, 291-309.

Giannetti, M. (2003). Do better institutions mitigate agency problems? Evidence from corporate finance choices. Journal of Financial and Quantitative Analysis, 38 (1), 185-212.

González, V.M., \& González, F. (2008). Influence of bank concentration and institutions on capital structure: New international evidence. Journal of Corporate Finance, 14 (4), 363-375.

Huang, R, \& Ritter, J.R. (2009). Testing theories of capital structure and estimating the speed of adjustment. Journal of Financial and Quantitative Analysis, 44 (2), 237-271.

Jiraporn, P., Kim, J., Kim, Y.S., \& Kitsabunnarat, P. (2012). Capital structure and corporate governance quality: Evidence from the Institutional Shareholder Services (ISS). International Review of Economics and Finance, 22, 208-221.

Kaminsky, G., \& Reinhart, C. M. (1999). The twin crises: The causes of banking and balance of payments problems. American Economic Review, 89 (3), 473-500.

Keeley, M.C. (1990). Deposit insurance, risk and market power in banking. American Economic Review, 80, 1183-1200.

Klein, M. (1971). A theory of the banking firm. Journal of Money, Credit, and Banking, 3, 205-218.

Laeven, L. (2003). Does financial liberalization reduce financing constraints?. Financial Management, 32, 5-34.

La Porta, R., Lopez-de-Silanes, F., Shleifer, A., \& Vishny, R.W. (1997). Legal determinants of external finance. Journal of Finance, 53, 1131-1150. 
La Porta, R., Lopez-de-Silanes, F., Shleifer, A., \& Vishny, R.W. (1998). Law and finance. Journal of Political Economy, 106, 1113-1155.

Leary, M., \& Roberts, M. (2005). Do firms rebalance their capital structure?. Journal of Finance, 60 (6), 2575-2619.

Levine, R. (1997). Financial development and economic growth: views and agenda. Journal of Economic Literature, 35, 688-726.

Levine, R. (1999). Law, finance and economic growth. Journal of Financial Intermediation, 8, 8-35.

Levine, R., Loayza, N., \& Beck, T. (2000). Financial intermediation and growth: Causality and causes. Journal of Monetary Economics, 46, 31-77.

Petersen, M., \& Rajan, R. (1994). The benefits of lending relationship: evidence from small business data. Journal of Finance, 49, 3-37.

Petersen, M., \& Rajan, R. (1995). The effect of credit market competition on lending relationships. Quarterly Journal of Economics, May, 407-443

Qian, J., \& Strahan, P.E. (2007). How law and institutions shape financial contracts: The case of bank loans. Journal of Finance, 62, 2803-2834.

Rajan, R.G., \& Zingales, L. (1995). What do we know about capital structure? Some evidence from international data. Journal of Finance, 50 (5), 1421-1460.

Rajan, R. G., \& Zingales, L. (1998). Financial dependence and growth. American Economic Review, 88, 559-586.

Schmukler, S.L., \& Vesperoni, E. (2006). Financial globalization and debt maturity in emerging economies. Journal of Development Economics, 79, 183-207.

Welch, I. (2004). Capital structure and stock returns. Journal of Political Economy, $112(1), 106-131$.

Zarutskie, R. (2006). Evidence on the effects of bank competition on firm borrowing and investment. Journal of Financial Economics, 81, 503-537. 
Figure 1. Evolution of banking liberalization

The figure shows the evolution of Financial Freedom during the period 1995-2004. Financial Freedom is one of the 10 aspects measured in the Index of Economic Freedom established by the Heritage Foundation. It is scored by determining the extent of government regulation of financial services; the extent of state intervention in banks and other financial services; the difficulty of opening and operating financial services firms; and government influence on the allocation of credit. It is scored on a scale of 0 to 100 , where higher values indicate lower restrictions on banking. DEVELOPED countries are countries classified as high income and upper middle income and DEVELOPING countries are countries classified as low income and lower middle income according to GNI per capita, calculated using the World Bank's Atlas method.

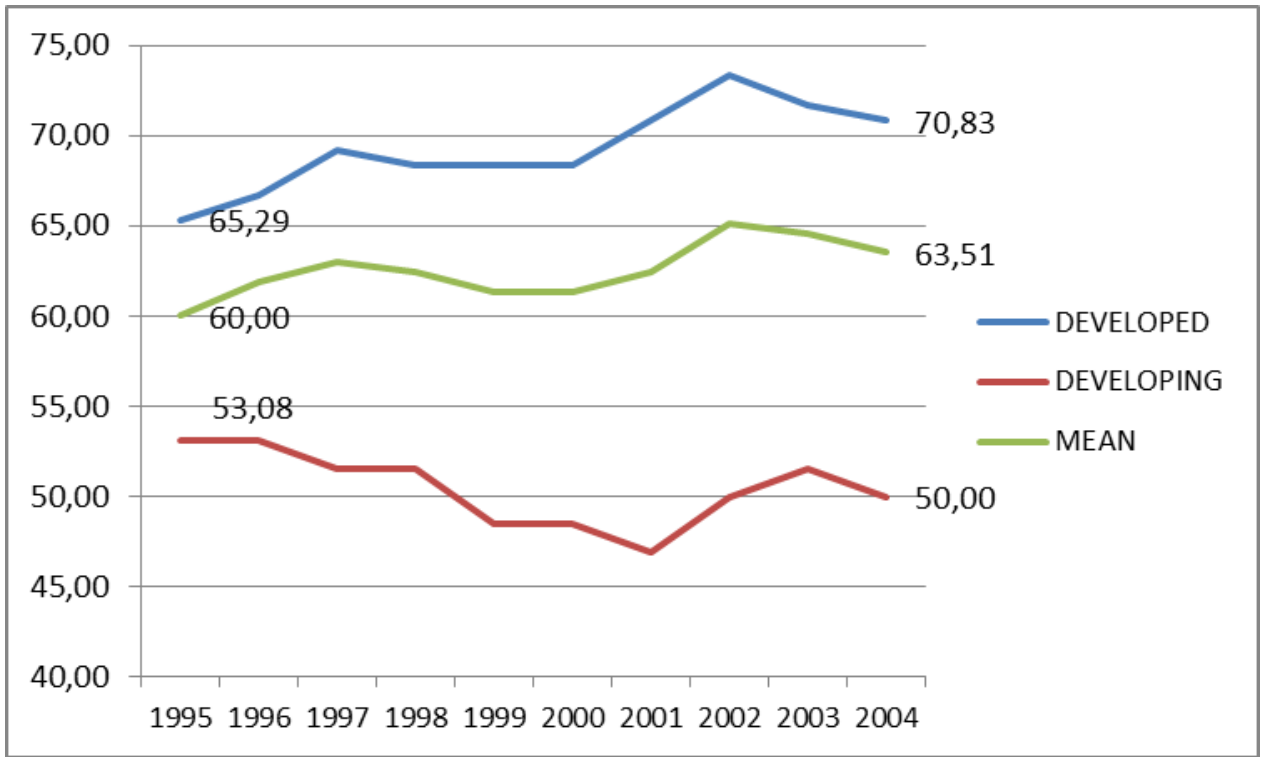


Table 1. Descriptive Statistics (I)

Table 1 reports the descriptive statistics of firm-level and country-level variables. TOTAL DEBT is the ratio between the book value of debt (long-term and short-term debt) and the market value of total assets; LONG-TERM DEBT is the ratio between the book value of long-term debt and the market value of total assets; SHORT-TERM DEBT is the ratio between the book value of short-term debt and the market value of total assets; PROFIT is estimated as EBIT plus depreciation expenses and provisions (non-cash deductions from earnings) divided by total assets; GROWTH is growth opportunities and is measured by Tobin's Q; PPE is the ratio between tangible assets (property, plant and equipment) and total assets; SIZE is the natural logarithm of firms' sales; BFREEDOM measures the openness of the banking and financial system. PRBOND is the percentage of the private domestic debt over GDP; CONC is the fraction of assets held by the three largest commercial banks in each country; RIGHTS measures the protection of property rights; CREDITORS measures creditor rights; ENFORCE measures the country's legal enforcement; OFFICIAL measures the extent to which official supervisors have the authority to take specific actions to prevent and correct problems; MONITOR measures the degree of private oversight.

\begin{tabular}{|c|c|c|c|c|c|}
\hline & MEAN & MEDIAN & $\begin{array}{l}\text { STANDARD } \\
\text { DEVIATION }\end{array}$ & MINIMUM & MAXIMUM \\
\hline TOTAL DEBT (\%) & 26.3 & 20.8 & 23.52 & 0 & 83.86 \\
\hline LONG-TERM DEBT (\%) & 12.82 & 7.91 & 14.14 & 0 & 56.85 \\
\hline SHORT-TERM DEBT (\%) & 11.17 & 4.93 & 13.93 & 0 & 59.11 \\
\hline PROFIT (\%) & 9.28 & 10.94 & 32.87 & -33.26 & 44.1 \\
\hline GROWTH & 2.97 & 1.5 & 30.17 & 0 & 7426.01 \\
\hline $\operatorname{PPE}(\%)$ & 32.17 & 28.91 & 33.43 & 0 & 72.46 \\
\hline SIZE & 5.15 & 5.17 & 2.1 & -11.62 & 12.44 \\
\hline BFREEDOM & 65.21 & 70 & 19.37 & 30 & 90 \\
\hline PRBOND & 46.33 & 43.7 & 34.36 & 0 & 130.22 \\
\hline CONC (\%) & 50.04 & 45.67 & 18.76 & 26.04 & 99.87 \\
\hline RIGHTS & 1.46 & 1 & 0.75 & 1 & 4 \\
\hline CREDITORS & 2.12 & 2 & 1.26 & 0 & 4 \\
\hline ENFORCE & 8.62 & 9.37 & 1.5 & 2.9 & 9.99 \\
\hline OFFICIAL & 11.26 & 12 & 2.72 & 3 & 15 \\
\hline MONITOR & 7.68 & 8 & 1.25 & 5 & 12 \\
\hline
\end{tabular}


Table 2. Descriptive Statistics (II)

Table 2 reports the descriptive statistics of country-level variables across countries. Descriptive statistics are split between developed and developing countries according to GNI per capita, calculated using the World Bank's Atlas method. BFREEDOM measures the openness of the banking and financial system. PRBOND is the percentage of private domestic debt over GDP; CONC is the fraction of assets held by the three largest commercial banks in each country; RIGHTS measures the protection of property rights; CREDITORS measures creditor rights; ENFORCE measures the country's legal enforcement; OFFICIAL measures the extent to which official supervisors have the authority to take specific actions to prevent and correct problems; MONITOR measures the degree of private oversight.

\begin{tabular}{|c|c|c|c|c|c|c|c|c|}
\hline & BFREEDOM & PRBOND & CONC (\%) & RIGHTS & CREDITORS & ENFORCE & OFFICIAL & MONITOR \\
\hline \multicolumn{9}{|l|}{ Developed } \\
\hline Argentina & 56.90 & 6.93 & 41.16 & 3.16 & 1.00 & 5.79 & 12 & 8 \\
\hline Australia & 90.00 & 29.56 & 63.78 & 5.00 & 3.00 & 9.30 & 12 & 10 \\
\hline Austria & 75.84 & 34.33 & 67.73 & 5.00 & 3.00 & 9.47 & 14 & 6 \\
\hline Belgium & 70.00 & 43.95 & 87.94 & 5.00 & 2.00 & 9.49 & 10 & 8 \\
\hline Canada & 70.00 & 19.54 & 54.61 & 5.00 & 1.00 & 9.58 & 9 & 9 \\
\hline Denmark & 77.18 & 109.26 & 78.29 & 5.00 & 3.00 & 9.80 & 9 & 7 \\
\hline Finland & 57.91 & 23.64 & 98.37 & 5.00 & 1.00 & 9.80 & 9 & 9 \\
\hline France & 50.00 & 42.89 & 56.00 & 4.00 & 0.00 & 8.97 & 8 & 6 \\
\hline Germany & 53.90 & 52.76 & 64.60 & 5.00 & 3.00 & 9.37 & 11 & 5 \\
\hline Greece & 40.66 & 0.62 & 70.10 & 3.60 & 1.00 & 6.82 & 10 & 6 \\
\hline Hong Kong & 89.17 & 17.32 & 68.77 & 5.00 & 4.00 & 8.77 & 10 & 8 \\
\hline Ireland & 79.09 & 9.50 & 63.29 & 5.00 & 1.00 & 8.40 & 11 & 6 \\
\hline Italy & 67.91 & 37.27 & 38.28 & 4.00 & 2.00 & 7.95 & 6 & 6 \\
\hline Japan & 48.26 & 46.23 & 37.55 & 4.63 & 1.76 & 9.37 & 13 & 8 \\
\hline Netherlands & 90.00 & 48.17 & 70.11 & 5.00 & 3.00 & 9.87 & 8 & 6 \\
\hline New Zealand & 90.00 & 0.00 & 75.02 & 5.00 & 4.00 & 9.80 & 7 & 8 \\
\hline Norway & 50.00 & 21.63 & 89.98 & 5.00 & 2.00 & 9.76 & 8 & 10 \\
\hline Portugal & 50.00 & 22.58 & 85.46 & 4.00 & 1.00 & 7.81 & 13 & 8 \\
\hline Singapore & 70.00 & 18.95 & 91.99 & 5.00 & 3.00 & 8.99 & 3 & 9 \\
\hline Spain & 66.54 & 17.54 & 57.88 & 4.00 & 2.00 & 7.87 & 10 & 8 \\
\hline Sweden & 75.88 & 43.77 & 97.54 & 4.52 & 1.05 & 9.92 & 6 & 6 \\
\hline Switzerland & 88.40 & 41.98 & 78.41 & 4.92 & 1.00 & 9.99 & 13 & 8 \\
\hline UK & 90.00 & 17.31 & 48.51 & 5.00 & 4.00 & 9.40 & 12 & 8 \\
\hline US & 79.41 & 1.01 & 29.46 & 5.00 & 1.00 & 9.52 & 14 & 8 \\
\hline Mean & 69.88 & 29.45 & 67.28 & 4.66 & 1.96 & 8.99 & 9.92 & 7.54 \\
\hline Median & 70.00 & 23.11 & 68.25 & 5.00 & 2.00 & 9.39 & 10.00 & 8.00 \\
\hline Standard dev & 15.78 & 23.39 & 19.44 & 0.55 & 1.12 & 1.06 & 2.78 & 1.38 \\
\hline Minimum & 40.66 & 0.00 & 29.46 & 3.16 & 0.00 & 5.79 & 3.00 & 5.00 \\
\hline Maximum & 90.00 & 109.26 & 98.37 & 5.00 & 4.00 & 9.99 & 14.00 & 10.00 \\
\hline \multicolumn{9}{|l|}{ Developing } \\
\hline Brazil & 50.00 & 10.58 & 42.83 & 3.00 & 1.00 & 6.52 & 15 & 8 \\
\hline Chile & 57.64 & 19.97 & 55.52 & 5.00 & 2.00 & 5.66 & 11 & 8 \\
\hline India & 30.00 & 0.59 & 36.32 & 3.00 & 2.00 & 6.12 & 9 & 6 \\
\hline Indonesia & 35.56 & 1.67 & 59.57 & 2.46 & 2.23 & 2.90 & 14 & 8 \\
\hline Malaysia & 38.35 & 49.62 & 44.75 & 3.42 & 3.00 & 7.71 & 11 & 9 \\
\hline Mexico & 46.43 & 2.34 & 66.98 & 3.06 & 0.00 & 5.99 & 10 & 6 \\
\hline Pakistan & 51.14 & 0.00 & 59.58 & 2.64 & 1.00 & 3.67 & 6 & 12 \\
\hline Peru & 70.00 & 3.45 & 72.12 & 2.67 & 0.00 & 4.83 & 14 & 8 \\
\hline Philippines & 50.00 & 0.08 & 49.92 & 3.35 & 1.00 & 4.08 & 12 & 8 \\
\hline South Africa & 55.53 & 9.99 & 73.91 & 3.00 & 3.00 & 6.44 & 4 & 8 \\
\hline South Korea & 53.70 & 46.11 & 45.30 & 4.69 & 3.00 & 6.71 & 10 & 6 \\
\hline Thailand & 50.00 & 13.21 & 52.59 & 4.07 & 2.29 & 5.93 & 11 & 6 \\
\hline Turkey & 58.19 & 0.03 & 62.04 & 3.54 & 2.00 & 5.46 & 11 & 6 \\
\hline Mean & 49.73 & 12.13 & 55.49 & 3.38 & 1.73 & 5.54 & 10.62 & 7.62 \\
\hline Median & 50.00 & 3.45 & 55.52 & 3.06 & 2.00 & 5.93 & 11.00 & 8.00 \\
\hline Standard dev & 10.52 & 17.03 & 11.58 & 0.78 & 1.05 & 1.34 & 3.07 & 1.71 \\
\hline Minimum & 30.00 & 0.00 & 36.32 & 2.46 & 0.00 & 2.90 & 4.00 & 6.00 \\
\hline Maximum & 70.00 & 49.62 & 73.91 & 5.00 & 3.00 & 7.71 & 15.00 & 12.00 \\
\hline
\end{tabular}


Table 3. Banking liberalization and firm leverage

Regressions are estimated using the Arellano and Bond (1991) two-step GMM difference estimator for panel data with lagged dependent variables. Three dependent variables are used: total, short-term, and long-term debt. The dependent variables are measured as the ratio between the book value of debt and the market value of total assets. As explanatory variables, we include one lag or two lags of the dependent variable (DEBT $\mathrm{t}_{-1}$ and $\mathrm{DEBT}_{\mathrm{t}-2)}$; PROFIT is estimated as EBIT plus depreciation expenses and provisions (non-cash deductions from earnings) divided by total assets; GROWTH is growth opportunities and is measured by Tobin's Q. PPE is the ratio between tangible assets (property, plant and equipment) and total assets; SIZE is the natural logarithm of sales; PRBOND is the percentage of private domestic debt over GDP; CONC is the fraction of assets held by the three largest commercial banks in each country; RIGHTS measures the protection of property rights; CREDITORS measures the protection of creditor rights; ENFORCE measures the country's legal enforcement; BFREEDOM measures the openness of the banking and financial system. T-statistics are in parentheses. $* * *, * *$ and $*$ represent significance at the $1 \%, 5 \%$, and $10 \%$ levels, respectively.

\begin{tabular}{|c|c|c|c|c|c|c|}
\hline & \multicolumn{2}{|c|}{ Total debt } & \multicolumn{2}{|c|}{ Short-term debt } & \multicolumn{2}{|c|}{ Long-term debt } \\
\hline & (1) & (2) & (3) & (4) & (5) & (6) \\
\hline Intercept & $\begin{array}{l}-0.0090 \\
(-1.40)\end{array}$ & $\begin{array}{l}-0.0113 * \\
(-1.65)\end{array}$ & $\begin{array}{l}-0.0048 \\
(-1.39)\end{array}$ & $\begin{array}{l}-0.0057^{*} \\
(-1.66)\end{array}$ & $\begin{array}{l}-0.0060 \\
(-1.28)\end{array}$ & $\begin{array}{l}-0.0055 \\
(-1.11)\end{array}$ \\
\hline $\operatorname{DEBT}_{t-1}$ & $\begin{array}{l}0.7050^{* * *} \\
(7.41)\end{array}$ & $\begin{array}{l}0.7123 \text { *** } \\
(6.48)\end{array}$ & $\begin{array}{l}0.5192 * * * \\
(13.14)\end{array}$ & $\begin{array}{l}0.5301 * * * \\
(14.87)\end{array}$ & $\begin{array}{l}0.6290 * * * \\
(8.00)\end{array}$ & $\begin{array}{l}0.6322 * * * \\
(7.73)\end{array}$ \\
\hline $\mathrm{DEBT}_{\mathrm{t}-2}$ & & & $\begin{array}{l}0.0700^{* * * *} \\
(5.55)\end{array}$ & $\begin{array}{l}0.0734 * * * \\
(5.86)\end{array}$ & $\begin{array}{l}0.0014 \\
(0.006)\end{array}$ & $\begin{array}{l}0.0053 \\
(0.23)\end{array}$ \\
\hline PROFIT & $\begin{array}{l}0.1928 \\
(0.88)\end{array}$ & $\begin{array}{l}0.2556 \\
(1.00)\end{array}$ & $\begin{array}{l}-0.0400 \\
(-0.39)\end{array}$ & $\begin{array}{l}0.0016 \\
(0.02)\end{array}$ & $\begin{array}{l}-0.0723 \\
(-0.47)\end{array}$ & $\begin{array}{l}-0.0426 \\
(-0.26)\end{array}$ \\
\hline GROWTH & $\begin{array}{l}-0.0112 \\
(-1.39)\end{array}$ & $\begin{array}{l}-0.0100 \\
(-1.17)\end{array}$ & $\begin{array}{l}-0.0042 \\
(-0.65)\end{array}$ & $\begin{array}{l}-0.0034 \\
(-0.71)\end{array}$ & $\begin{array}{l}-0.0008 \\
(-0.29)\end{array}$ & $\begin{array}{l}-0.0010 \\
(-0.39)\end{array}$ \\
\hline PPE & $\begin{array}{l}0.5624 * * \\
(2.52)\end{array}$ & $\begin{array}{l}0.6019 * * \\
(2.36)\end{array}$ & $\begin{array}{l}0.1904 * * \\
(1.97)\end{array}$ & $\begin{array}{l}0.2447 * * \\
(2.46)\end{array}$ & $\begin{array}{l}0.3490 * * \\
(2.49)\end{array}$ & $\begin{array}{l}0.3707 * * \\
(2.41)\end{array}$ \\
\hline SIZE & $\begin{array}{l}0.2057 * * \\
(2.43)\end{array}$ & $\begin{array}{l}0.1981^{* *} \\
(2.29)\end{array}$ & $\begin{array}{l}0.0775^{* *} \\
(2.37)\end{array}$ & $\begin{array}{l}0.0919 * * * \\
(2.87)\end{array}$ & $\begin{array}{l}0.0614 \\
(0.96)\end{array}$ & $\begin{array}{l}0.0556 \\
(0.88)\end{array}$ \\
\hline PRBOND & $\begin{array}{l}-0.0816 \\
(-1.43)\end{array}$ & $\begin{array}{l}-0.2095^{* * *} \\
(-3.68)\end{array}$ & $\begin{array}{l}-0.0290 \\
(-0.96)\end{array}$ & $\begin{array}{l}-0.0772 * * * \\
(-3.07)\end{array}$ & $\begin{array}{l}-0.0517 \\
(-1.61)\end{array}$ & $\begin{array}{l}-0.0842^{* *} \\
(-2.17)\end{array}$ \\
\hline $\mathrm{CONC}$ & & $\begin{array}{l}-0.2762 * * * \\
(-2.65)\end{array}$ & & $\begin{array}{l}-0.1318^{* *} \\
(-2.36)\end{array}$ & & $\begin{array}{l}-0.0354 \\
(-0.62)\end{array}$ \\
\hline RIGHTS x ENFORCE & & $\begin{array}{l}-0.0036^{* * *} \\
(-2.96)\end{array}$ & & $\begin{array}{l}-0.0021^{* * *} \\
(-4.67)\end{array}$ & & $\begin{array}{l}-0.0012 * \\
(-1.92)\end{array}$ \\
\hline CREDITORS x ENFORCE & & $\begin{array}{l}0.0026^{* *} \\
(2.32)\end{array}$ & & $\begin{array}{l}0.0007 \\
(1.59)\end{array}$ & & $\begin{array}{l}0.0016^{*} \\
(1.85)\end{array}$ \\
\hline BFREEDOM & $\begin{array}{l}0.0005 * * \\
(2.45)\end{array}$ & $\begin{array}{l}0.0008^{* * * *} \\
(3.57)\end{array}$ & $\begin{array}{l}0.0006^{* * *} \\
(4.21)\end{array}$ & $\begin{array}{l}0.0007 * * * \\
(6.41)\end{array}$ & $\begin{array}{l}-0.0000 \\
(-0.26)\end{array}$ & $\begin{array}{l}0.0000 \\
(0.21)\end{array}$ \\
\hline BFREEDOM $_{\mathrm{t}-1}$ & $\begin{array}{l}0.0011^{* *} \\
(2.29)\end{array}$ & $\begin{array}{l}0.0011^{* *} \\
(2.26)\end{array}$ & $\begin{array}{l}0.0001 \\
(0.72)\end{array}$ & $\begin{array}{l}0.0003 \\
(1.29)\end{array}$ & $\begin{array}{l}0.0005 \\
(1.35)\end{array}$ & $\begin{array}{l}0.0005 \\
(1.26)\end{array}$ \\
\hline BFREEDOM $_{\mathrm{t}-2}$ & $\begin{array}{l}0.0006 \\
(0.80)\end{array}$ & $\begin{array}{l}0.0004 \\
(0.59)\end{array}$ & $\begin{array}{l}0.0005 \\
(1.23)\end{array}$ & $\begin{array}{l}0.0006 \\
(1.49)\end{array}$ & $\begin{array}{l}-0.0002 \\
(-0.36)\end{array}$ & $\begin{array}{l}-0.0003 \\
(-0.55)\end{array}$ \\
\hline Country-Industry Dummies & Yes & Yes & Yes & Yes & Yes & Yes \\
\hline Industry-Year Dummies & Yes & Yes & Yes & Yes & Yes & Yes \\
\hline Country-Year Dummies & Yes & Yes & Yes & Yes & Yes & Yes \\
\hline $\mathrm{m}_{2}$ & -0.97 & -0.76 & -0.49 & -0.26 & 0.56 & 0.39 \\
\hline \# observations & 41,262 & 41,145 & 40,830 & 40,710 & 40,377 & 40,265 \\
\hline \# firms & 9,822 & 9,820 & 9,656 & 9,655 & 9,705 & 9,703 \\
\hline Sargan test & 1.00 & 2.21 & 1.86 & 1.75 & 1.06 & 1.02 \\
\hline
\end{tabular}




\section{Table 4. Banking liberalization, supervision, and firm leverage}

Regressions are estimated using the Arellano and Bond (1991) two-step GMM difference estimator for panel data with lagged dependent variables. Three dependent variable are used: total, short-term, and long-term debt. The dependent variables are measured as the ratio between the book value of debt and the market value of total assets. As explanatory variables, we include one lag or two lags of the dependent variable (DEBT $\mathrm{t}_{-1}$ and $\mathrm{DEBT}_{\mathrm{t}-2}$ ); PROFIT is estimated as EBIT plus depreciation expenses and provisions (non-cash deductions from earnings) divided by total assets; GROWTH is growth opportunities and is measured by Tobin's Q. PPE is the ratio between tangible assets (property, plant and equipment) and total assets; SIZE is the natural logarithm of sales; PRBOND is the percentage of private domestic debt over GDP; CONC is the fraction of assets held by the three largest commercial banks in each country; RIGHTS measures the protection of property rights; CREDITORS measures the protection of creditor rights; ENFORCE measures the country's legal enforcement; BFREEDOM measures the openness of the banking and financial system; OFFICIAL measures the extent to which official supervisors have the authority to take specific actions to prevent and correct problems; MONITOR measures the degree of private oversight. T-statistics are in parentheses. $* * *, * *$ and $*$ represent significance at the $1 \%, 5 \%$, and $10 \%$ levels, respectively.

\begin{tabular}{|c|c|c|c|c|c|c|c|c|c|}
\hline & \multicolumn{3}{|c|}{ Total debt } & \multicolumn{3}{|c|}{ Short-term debt } & \multicolumn{3}{|c|}{ Long-term debt } \\
\hline & $(1)$ & $(2)$ & (3) & (4) & (5) & $(6)$ & (7) & $(8)$ & (9) \\
\hline Intercept & $\begin{array}{c}-0.0070 \\
(-0.70)\end{array}$ & $\begin{array}{c}-0.0070 \\
(-0.87)\end{array}$ & $\begin{array}{c}-0.0043 \\
(-0.44)\end{array}$ & $\begin{array}{l}-0.0018 \\
(-0.43)\end{array}$ & $\begin{array}{c}-0.0029 \\
(-0.81)\end{array}$ & $\begin{array}{c}-0.0006 \\
(-0.15)\end{array}$ & $\begin{array}{c}-0.0053 \\
(-0.71)\end{array}$ & $\begin{array}{c}-0.0053 \\
(-0.87)\end{array}$ & $\begin{array}{c}-0.0049 \\
(-0.64)\end{array}$ \\
\hline $\mathrm{DEBT}_{\mathrm{t}-1}$ & $\begin{array}{c}0.7176 * * * \\
(6.57)\end{array}$ & $\begin{array}{c}0.7082 * * * \\
(6.50)\end{array}$ & $\begin{array}{c}0.7138 * * * \\
\quad(6.53)\end{array}$ & $\begin{array}{c}0.5221 * * * \\
(14.96)\end{array}$ & $\begin{array}{c}0.5217 * * * \\
(14.22)\end{array}$ & $\begin{array}{c}0.5177 * * * \\
(14.80)\end{array}$ & $\begin{array}{c}0.6268 * * * \\
(7.38)\end{array}$ & $\begin{array}{c}0.6298 * * * \\
(7.73)\end{array}$ & $\begin{array}{c}0.6257 * * * \\
(7.31)\end{array}$ \\
\hline $\mathrm{DEBT}_{\mathrm{t}-2}$ & & & & $\begin{array}{c}0.0701 * * * \\
(5.57)\end{array}$ & $\begin{array}{c}0.0707 * * * \\
(5.63)\end{array}$ & $\begin{array}{c}0.0685^{* * *} \\
\quad(5.43)\end{array}$ & $\begin{array}{c}0.0066 \\
(0.30)\end{array}$ & $\begin{array}{l}0.0064 \\
(0.28)\end{array}$ & $\begin{array}{c}0.0072 \\
(0.32)\end{array}$ \\
\hline PROFIT & $\begin{array}{c}0.2319 \\
(0.85)\end{array}$ & $\begin{array}{c}0.2480 \\
(0.94)\end{array}$ & $\begin{array}{c}0.2304 \\
(0.84)\end{array}$ & $\begin{array}{c}0.0087 \\
(0.12)\end{array}$ & $\begin{array}{c}0.0044 \\
(0.06)\end{array}$ & $\begin{array}{c}0.0098 \\
(0.14)\end{array}$ & $\begin{array}{c}-0.0296 \\
(-0.17)\end{array}$ & $\begin{array}{c}-0.0429 \\
(-0.26)\end{array}$ & $\begin{array}{c}-0.0302 \\
(-0.17)\end{array}$ \\
\hline GROWTH & $\begin{array}{c}-0.0084 \\
(-0.97)\end{array}$ & $\begin{array}{c}-0.0095 \\
(-1.09)\end{array}$ & $\begin{array}{c}-0.0082 \\
(-0.95)\end{array}$ & $\begin{array}{c}-0.0029 \\
(-0.71)\end{array}$ & $\begin{array}{c}-0.0033 \\
(-0.72)\end{array}$ & $\begin{array}{c}-0.0029 \\
(-0.71)\end{array}$ & $\begin{array}{c}-0.0008 \\
(-0.34)\end{array}$ & $\begin{array}{c}-0.0009 \\
(-0.36)\end{array}$ & $\begin{array}{c}-0.0008 \\
(-0.31)\end{array}$ \\
\hline PPE & $\begin{array}{c}0.5973 * * \\
(2.24)\end{array}$ & $\begin{array}{c}0.5871 * * \\
(2.29)\end{array}$ & $\begin{array}{c}0.5867 * * \\
(2.17)\end{array}$ & $\begin{array}{c}0.2544 * * * \\
(2.58)\end{array}$ & $\begin{array}{c}0.2321 * * \\
(2.45)\end{array}$ & $\begin{array}{c}0.2485 * * * \\
\quad(2.51)\end{array}$ & $\begin{array}{c}0.3688^{* *} \\
(2.19)\end{array}$ & $\begin{array}{c}0.3677 * * \\
(2.37)\end{array}$ & $\begin{array}{c}0.3671^{* *} \\
(2.16)\end{array}$ \\
\hline SIZE & $\begin{array}{c}0.1951 * * \\
(2.08)\end{array}$ & $\begin{array}{c}0.2020^{* *} \\
(2.22)\end{array}$ & $\begin{array}{c}0.1984 * * \\
(2.08)\end{array}$ & $\begin{array}{c}0.0983 * * * \\
(3.02)\end{array}$ & $\begin{array}{c}0.0956^{* * *} * \\
(3.02)\end{array}$ & $\begin{array}{c}0.1002 * * * \\
\quad(3.11)\end{array}$ & $\begin{array}{c}0.0569 \\
(0.82)\end{array}$ & $\begin{array}{c}0.0559 \\
(0.84)\end{array}$ & $\begin{array}{l}0.0577 \\
(0.82)\end{array}$ \\
\hline PRBOND & $\begin{array}{c}-0.2281 * * * \\
(-3.61)\end{array}$ & $\begin{array}{c}-0.2304 * * * \\
(-3.78)\end{array}$ & $\begin{array}{c}-0.2433 * * * \\
(-3.89)\end{array}$ & $\begin{array}{c}-0.0844 * * * \\
(-3.14)\end{array}$ & $\begin{array}{c}-0.0901 * * * \\
(-3.51)\end{array}$ & $\begin{array}{c}-0.0896 * * * \\
(-3.30)\end{array}$ & $\begin{array}{c}-0.0872 * \\
(-1.85)\end{array}$ & $\begin{array}{c}-0.0853^{* *} \\
(-1.99)\end{array}$ & $\begin{array}{c}-0.0901 * \\
(-1.89)\end{array}$ \\
\hline CONC & $\begin{array}{c}-0.2482 * * \\
(-2.37)\end{array}$ & $\begin{array}{c}-0.2696^{* *} \\
(-2.37)\end{array}$ & $\begin{array}{c}-0.2509^{* *} \\
(-2.26)\end{array}$ & $\begin{array}{c}-0.1286^{* *} \\
(-2.50)\end{array}$ & $\begin{array}{c}-0.1358^{* *} \\
(-2.37)\end{array}$ & $\begin{array}{c}-0.1310^{* *} \\
(-2.53)\end{array}$ & $\begin{array}{c}-0.0309 \\
(-0.55)\end{array}$ & $\begin{array}{c}-0.0286 \\
(-0.48)\end{array}$ & $\begin{array}{l}-0.293 \\
(-0.52)\end{array}$ \\
\hline RIGHTS x ENFORCE & $\begin{array}{c}-0.0037 * * * \\
(-2.97)\end{array}$ & $\begin{array}{c}-0.0039^{* * *} \\
(-3.11)\end{array}$ & $\begin{array}{c}-0.0039^{* * *} \\
(-3.15)\end{array}$ & $\begin{array}{c}-0.0022 * * * \\
(-4.75)\end{array}$ & $\begin{array}{c}-0.0023 * * * \\
(-4.99)\end{array}$ & $\begin{array}{c}-0.0022 * * * \\
(-4.98)\end{array}$ & $\begin{array}{c}-0.0013 * \\
(-1.90)\end{array}$ & $\begin{array}{c}-0.0013 * \\
(-1.84)\end{array}$ & $\begin{array}{c}-0.0013 * \\
(-1.91)\end{array}$ \\
\hline CREDITORS x ENFORCE & $\begin{array}{c}0.0026 * * \\
(2.13)\end{array}$ & $\begin{array}{c}0.0027^{* *} \\
(2.30)\end{array}$ & $\begin{array}{c}0.0027 * * \\
(2.17)\end{array}$ & $\begin{array}{c}0.0008^{*} \\
(1.79)\end{array}$ & $\begin{array}{c}0.0007 * \\
(1.78)\end{array}$ & $\begin{array}{c}0.0008^{*} \\
(1.90)\end{array}$ & $\begin{array}{c}0.0016^{*} \\
(1.65)\end{array}$ & $\begin{array}{c}0.0016^{*} \\
(1.76)\end{array}$ & $\begin{array}{c}0.0016^{*} \\
(1.64)\end{array}$ \\
\hline BFREEDOM & $\begin{array}{c}-0.0003 \\
(-0.19)\end{array}$ & $\begin{array}{c}-0.0013 \\
(-1.03)\end{array}$ & $\begin{array}{c}-0.0019 \\
(-0.99)\end{array}$ & $\begin{array}{c}0.0002 \\
(0.35)\end{array}$ & $\begin{array}{r}-0.0007 \\
(-0.89)\end{array}$ & $\begin{array}{c}-0.0009 \\
(-1.06)\end{array}$ & $\begin{array}{l}0.0006 \\
(0.59)\end{array}$ & $\begin{array}{l}0.0005 \\
(0.62)\end{array}$ & $\begin{array}{l}0.0009 \\
(0.64)\end{array}$ \\
\hline BFREEDOM $_{\mathrm{t}-1}$ & $\begin{array}{c}-0.0047 * * * \\
(-3.66)\end{array}$ & $\begin{array}{c}-0.0028^{* *} \\
(-2.11)\end{array}$ & $\begin{array}{c}-0.0059^{* * * *} \\
(-3.51)\end{array}$ & $\begin{array}{c}-0.0015 * * * \\
(-2.71)\end{array}$ & $\begin{array}{r}-0.0005 \\
(-0.64)\end{array}$ & $\begin{array}{c}-0.0015^{*} \\
(-1.74)\end{array}$ & $\begin{array}{l}-0.0027 * * * \\
(-2.64)\end{array}$ & $\begin{array}{l}-0.0022 * * * \\
(-2.77)\end{array}$ & $\begin{array}{l}-0.0039 * * * \\
(-3.12)\end{array}$ \\
\hline BFREEDOM $_{\mathrm{t}-2}$ & $\begin{array}{l}0.0015 \\
(0.57)\end{array}$ & $\begin{array}{c}-0.0014 \\
(-0.97)\end{array}$ & $\begin{array}{c}-0.0003 \\
(-0.13)\end{array}$ & $\begin{array}{c}-0.0018 \\
(-1.41)\end{array}$ & $\begin{array}{c}-0.0017^{* *} \\
(-2.21)\end{array}$ & $\begin{array}{l}-0.0026^{* *} \\
(-2.05)\end{array}$ & $\begin{array}{l}0.0021 \\
(1.41)\end{array}$ & $\begin{array}{c}0.0009 \\
(0.95)\end{array}$ & $\begin{array}{c}0.0022 \\
(1.37)\end{array}$ \\
\hline BFREEDOM x OFFICIAL & $\begin{array}{l}0.0001 \\
(0.78)\end{array}$ & & $\begin{array}{l}0.0001 \\
(0.64)\end{array}$ & $\begin{array}{c}0.0000 \\
(1.04)\end{array}$ & & $\begin{array}{c}0.0000 \\
(0.73)\end{array}$ & $\begin{array}{c}-0.0000 \\
(-0.47)\end{array}$ & & $\begin{array}{c}-0.0000 \\
(-0.43)\end{array}$ \\
\hline BFREEDOM $_{\mathrm{t}-1}$ x OFFICIAL & $\begin{array}{c}0.0005 * * * \\
\quad(3.35)\end{array}$ & & $\begin{array}{l}0.0005 * * * \\
\quad(3.17)\end{array}$ & $\begin{array}{l}0.0002 * * * \\
\quad(2.72)\end{array}$ & & $\begin{array}{l}0.0002 * * * \\
\quad(2.73)\end{array}$ & $\begin{array}{l}0.0003 * * \\
(2.30)\end{array}$ & & $\begin{array}{l}0.0003 * * \\
(2.11)\end{array}$ \\
\hline BFREEDOM $_{\mathrm{t}-2}$ x OFFICIAL & $\begin{array}{r}-0.0001 \\
(-0.38)\end{array}$ & & $\begin{array}{c}-0.0002 \\
(-0.56)\end{array}$ & $\begin{array}{c}0.0002 \\
(1.49)\end{array}$ & & $\begin{array}{l}0.0002 \\
(1.25)\end{array}$ & $\begin{array}{c}-0.0002 \\
(-1.32)\end{array}$ & & $\begin{array}{c}-0.0002 \\
(-1.25)\end{array}$ \\
\hline BFREEDOM x MONITOR & & $\begin{array}{c}0.0003^{*} \\
(1.64)\end{array}$ & $\begin{array}{c}0.0002 \\
(1.52)\end{array}$ & & $\begin{array}{c}0.0002^{*} \\
(1.86)\end{array}$ & $\begin{array}{c}0.0002 * \\
(1.68)\end{array}$ & & $\begin{array}{r}-0.0001 \\
(-0.54)\end{array}$ & $\begin{array}{c}-0.0000 \\
(-0.43)\end{array}$ \\
\hline BFREEDOM $_{\mathrm{t}-1}$ x MONITOR & & $\begin{array}{l}0.0005^{* * *} \\
\quad(2.74)\end{array}$ & $\begin{array}{c}0.0002 \\
(1.08)\end{array}$ & & $\begin{array}{l}0.0001 \\
(1.01)\end{array}$ & $\begin{array}{c}-0.0000 \\
(-0.13)\end{array}$ & & $\begin{array}{c}0.0004 * * * \\
(2.80)\end{array}$ & $\begin{array}{c}0.0002 * * \\
(1.90)\end{array}$ \\
\hline BFREEDOM $_{\mathrm{t}-2} \mathrm{x}$ MONITOR & & $\begin{array}{l}0.0002 \\
(0.91)\end{array}$ & $\begin{array}{c}0.0003 \\
(1.22)\end{array}$ & & $\begin{array}{c}0.0003 * * \\
(2.28)\end{array}$ & $\begin{array}{c}0.0002 \\
(1.58)\end{array}$ & & $\begin{array}{c}-0.0002 \\
(-0.93)\end{array}$ & $\begin{array}{c}-0.0000 \\
(-0.13)\end{array}$ \\
\hline Country-Industry Dummies & Yes & Yes & Yes & Yes & Yes & Yes & Yes & Yes & Yes \\
\hline Industry-Year Dummies & Yes & Yes & Yes & Yes & Yes & Yes & Yes & Yes & Yes \\
\hline Country-Year Dummies & Yes & Yes & Yes & Yes & Yes & Yes & Yes & Yes & Yes \\
\hline $\mathrm{m}_{2}$ & -0.56 & -0.68 & -0.54 & -0.05 & -0.24 & -0.07 & 0.31 & 0.38 & 0.33 \\
\hline \# observations & 41,145 & 41,145 & 41,145 & 40,710 & 40,710 & 40,710 & 40,265 & 40,265 & 40,265 \\
\hline \# firms & 9,820 & 9,820 & 9,820 & 9,655 & 9,655 & 9,655 & 9,703 & 9,703 & 9,703 \\
\hline Sargan test & 3.08 & 2.14 & 2.94 & 1.69 & 1.66 & 1.62 & 1.28 & 1.15 & 1.33 \\
\hline
\end{tabular}




\section{Table 5. Banking liberalization, investor protection, and firm leverage}

Regressions are estimated using the Arellano and Bond (1991) two-step GMM difference estimator for panel data with lagged dependent variables. Three dependent variable are used: total, short-term, and long-term debt. The dependent variables are measured as the ratio between the book value of debt and the market value of total assets. As explanatory variables, we include one lag or two lags of the dependent variable (DEBT $\mathrm{t}_{-1}$ and $\mathrm{DEBT}_{\mathrm{t}-2)}$; PROFIT is estimated as EBIT plus depreciation expenses and provisions (non-cash deductions from earnings) divided by total assets; GROWTH is growth opportunities and is measured by Tobin's Q. PPE is the ratio between tangible assets (property, plant and equipment) and total assets; SIZE is the natural logarithm of sales; PRBOND is the percentage of private domestic debt over GDP; CONC is the fraction of assets held by the three largest commercial banks in each country; RIGHTS measures the protection of property rights; CREDITORS measures the protection of creditor rights; ENFORCE measures the country's legal enforcement; BFREEDOM measures the openness of the banking and financial system. T-statistics are in parentheses. $* * *, * *$ and $*$ represent significance at the $1 \%, 5 \%$ and $10 \%$ levels, respectively.

\begin{tabular}{|c|c|c|c|c|c|c|}
\hline & \multicolumn{2}{|c|}{ Total debt } & \multicolumn{2}{|c|}{ Short-term debt } & \multicolumn{2}{|c|}{ Long-term debt } \\
\hline & $(1)$ & $(2)$ & $(3)$ & $(4)$ & $(5)$ & $(6)$ \\
\hline Intercept & $\begin{array}{c}-0.0155^{*} \\
(-1.92)\end{array}$ & $\begin{array}{c}-0.0138^{* *} \\
(-1.99)\end{array}$ & $\begin{array}{c}-0.0082 * * * \\
(-2.79)\end{array}$ & $\begin{array}{c}-0.0080^{* *} \\
(2.55)\end{array}$ & $\begin{array}{l}-0.0062 \\
(-0.64)\end{array}$ & $\begin{array}{l}-0.0041 \\
(-0.44)\end{array}$ \\
\hline $\operatorname{DEBT}_{\mathrm{t}-1}$ & $\begin{array}{c}0.8769^{* * *} \\
(8.98)\end{array}$ & $\begin{array}{c}0.8974 * * * \\
(10.67)\end{array}$ & $\begin{array}{c}0.7016^{* * *} \\
\quad(4.60)\end{array}$ & $\begin{array}{c}0.6623 * * * \\
\quad(4.16)\end{array}$ & $\begin{array}{c}0.9952 * * * \\
\quad(4.62)\end{array}$ & $\begin{array}{c}0.9781 * * * \\
\quad(3.47)\end{array}$ \\
\hline $\mathrm{DEBT}_{\mathrm{t}-2}$ & & & $\begin{array}{c}0.0168 \\
(0.22)\end{array}$ & $\begin{array}{c}0.0300 \\
(0.39)\end{array}$ & $\begin{array}{c}-0.0701 \\
(-0.28)\end{array}$ & $\begin{array}{c}-0.0366 \\
(-0.12)\end{array}$ \\
\hline PROFIT & $\begin{array}{c}-0.1273 \\
(-0.66)\end{array}$ & $\begin{array}{c}-0.1015 \\
(-0.59)\end{array}$ & $\begin{array}{l}0.0267 \\
(0.26)\end{array}$ & $\begin{array}{l}0.0227 \\
(0.21)\end{array}$ & $\begin{array}{c}0.2766^{*} \\
(1.82)\end{array}$ & $\begin{array}{c}0.3008^{*} \\
(1.77)\end{array}$ \\
\hline GROWTH & $\begin{array}{l}0.0108 \\
(1.49)\end{array}$ & $\begin{array}{c}0.0133 * * \\
(2.01)\end{array}$ & $\begin{array}{r}-0.0017 \\
(-0.43)\end{array}$ & $\begin{array}{c}-0.0023 \\
(-0.52)\end{array}$ & $\begin{array}{l}0.0067 \\
(1.12)\end{array}$ & $\begin{array}{l}0.0079 \\
(1.20)\end{array}$ \\
\hline PPE & $\begin{array}{l}0.2661 \\
(1.61)\end{array}$ & $\begin{array}{c}0.3312 * \\
(1.92)\end{array}$ & $\begin{array}{c}0.1298 * * \\
(2.45)\end{array}$ & $\begin{array}{c}0.1368 * * * \\
\quad(2.54)\end{array}$ & $\begin{array}{c}0.3330 \\
(1.48)\end{array}$ & $\begin{array}{c}0.3925^{*} \\
(1.68)\end{array}$ \\
\hline SIZE & $\begin{array}{l}0.0584 \\
(0.72)\end{array}$ & $\begin{array}{l}0.0691 \\
(0.87)\end{array}$ & $\begin{array}{l}0.0609^{* * * *} \\
\quad(3.18)\end{array}$ & $\begin{array}{l}0.0596 * * * \\
\quad(2.73)\end{array}$ & $\begin{array}{l}0.0563 \\
(0.68)\end{array}$ & $\begin{array}{l}0.0710 \\
(0.74)\end{array}$ \\
\hline PRBOND & $\begin{array}{c}-0.1861 * * * \\
(-3.28)\end{array}$ & $\begin{array}{c}-0.2271 * * * \\
(-3.97)\end{array}$ & $\begin{array}{c}-0.0818^{* *} \\
(-2.30)\end{array}$ & $\begin{array}{c}-0.0912 * * * \\
(-2.65)\end{array}$ & $\begin{array}{c}-0.1248 * * * \\
(-3.07)\end{array}$ & $\begin{array}{c}-0.1314 * * * \\
(-3.13)\end{array}$ \\
\hline $\mathrm{CONC}$ & $\begin{array}{l}0.0109 \\
(0.20)\end{array}$ & $\begin{array}{l}0.0714 \\
(1.19)\end{array}$ & $\begin{array}{c}-0.0935^{* *} \\
(-2.17)\end{array}$ & $\begin{array}{c}-0.0863^{*} \\
(-1.82)\end{array}$ & $\begin{array}{c}0.0530 \\
(1.34)\end{array}$ & $\begin{array}{c}0.0788^{* *} \\
(1.98)\end{array}$ \\
\hline RIGHTS x ENFORCE & $\begin{array}{c}-0.0009 \\
(-0.22)\end{array}$ & $\begin{array}{c}-0.0047 * * * \\
(-3.08)\end{array}$ & $\begin{array}{c}-0.0023^{*} \\
(-1.80)\end{array}$ & $\begin{array}{c}-0.0018 * * * \\
(-3.58)\end{array}$ & $\begin{array}{c}-0.0012 \\
(-0.35)\end{array}$ & $\begin{array}{c}-0.0026 \\
(-1.54)\end{array}$ \\
\hline CREDITORS $x$ ENFORCE & $\begin{array}{l}0.0013 \\
(1.17)\end{array}$ & $\begin{array}{l}0.0145^{* *} \\
(2.45)\end{array}$ & $\begin{array}{c}0.0002 \\
(0.78)\end{array}$ & $\begin{array}{l}0.0055^{* * * *} \\
\quad(3.54)\end{array}$ & $\begin{array}{c}0.0019^{*} \\
(1.68)\end{array}$ & $\begin{array}{l}0.0116 \\
(1.25)\end{array}$ \\
\hline BFREEDOM & $\begin{array}{l}0.0047 * * * \\
\quad(6.74)\end{array}$ & $\begin{array}{l}0.0019^{* * * *} \\
(4.23)\end{array}$ & $\begin{array}{l}0.0022 * * * \\
(4.33)\end{array}$ & $\begin{array}{c}0.0013^{* * * *} \\
\quad(4.79)\end{array}$ & $\begin{array}{c}0.0013^{*} \\
(1.85)\end{array}$ & $\begin{array}{l}0.0012 * * \\
(2.30)\end{array}$ \\
\hline BFREEDOM $_{\mathrm{t}-1}$ & $\begin{array}{c}-0.0041 * * * \\
(-3.16)\end{array}$ & $\begin{array}{c}0.0028^{* *} \\
(2.36)\end{array}$ & $\begin{array}{c}-0.0018 * * * \\
(-2.96)\end{array}$ & $\begin{array}{c}0.0009^{* *} \\
(2.19)\end{array}$ & $\begin{array}{c}-0.0022^{* *} \\
(-2.12)\end{array}$ & $\begin{array}{c}0.0022 * \\
(1.79)\end{array}$ \\
\hline BFREEDOM $_{\mathrm{t}-2}$ & $\begin{array}{l}0.0023^{* * *} \\
\quad(3.69)\end{array}$ & $\begin{array}{c}-0.0019^{* *} \\
(-2.08)\end{array}$ & $\begin{array}{c}0.0004 \\
(0.79)\end{array}$ & $\begin{array}{l}0.0002 \\
(0.29)\end{array}$ & $\begin{array}{l}0.0018^{* * * *} \\
\quad(2.70)\end{array}$ & $\begin{array}{c}-0.0014 \\
(-0.61)\end{array}$ \\
\hline BFREEDOM $_{t}$ x RIGHTS $x$ ENFORCE & $\begin{array}{c}-0.0001 * * * \\
(-5.49)\end{array}$ & & $\begin{array}{c}-0.00004 * * * \\
(-3.11)\end{array}$ & & $\begin{array}{c}-0.0000 \\
(-1.44)\end{array}$ & \\
\hline BFREEDOM $_{\mathrm{t}-1}$ x RIGHTS x ENFORCE & $\begin{array}{l}0.0001 * * * \\
\quad(2.62)\end{array}$ & & $\begin{array}{c}0.00005 * * * \\
(2.99)\end{array}$ & & $\begin{array}{c}0.0001^{* *} \\
(2.10)\end{array}$ & \\
\hline BFREEDOM $_{\mathrm{t}-2} \mathrm{x}$ RIGHTS $\mathrm{x}$ ENFORCE & $\begin{array}{c}-0.0001 * * * \\
(-5.41)\end{array}$ & & $\begin{array}{c}-0.0000 \\
(-0.21)\end{array}$ & & $\begin{array}{c}-0.0001 * * * \\
(-4.23)\end{array}$ & \\
\hline BFREEDOM x CREDITORS x ENFORCE & & $\begin{array}{c}-0.0001 * * * \\
(-3.63)\end{array}$ & & $\begin{array}{c}-0.0001^{* *} \\
(-2.46)\end{array}$ & & $\begin{array}{c}-0.0001 \\
(-1.52)\end{array}$ \\
\hline BFREEDOM $_{\mathrm{t}-1}$ x CREDITORS x ENFORCE & & $\begin{array}{c}-0.0002 * * * \\
(-3.03)\end{array}$ & & $\begin{array}{c}-0.0001^{* *} \\
(-2.53)\end{array}$ & & $\begin{array}{c}-0.0001^{*} \\
(-1.78)\end{array}$ \\
\hline BFREEDOM $_{\mathrm{t}-2}$ x CREDITORS x ENFORCE & & $\begin{array}{l}0.0000 \\
(0.29)\end{array}$ & & $\begin{array}{c}0.0000 \\
(0.26)\end{array}$ & & $\begin{array}{r}0.0000 \\
(0.01)\end{array}$ \\
\hline Country-Industry Dummies & Yes & Yes & Yes & Yes & Yes & Yes \\
\hline Industry-Year Dummies & Yes & Yes & Yes & Yes & Yes & Yes \\
\hline Country-Year Dummies & Yes & Yes & Yes & Yes & Yes & Yes \\
\hline $\mathrm{m}_{2}$ & 1.09 & 1.08 & 0.79 & 0.59 & 0.75 & 0.53 \\
\hline \# observations & 41,145 & 41,145 & 40,710 & 40,710 & 40,265 & 40,265 \\
\hline \# firms & 9,820 & 9,820 & 9,655 & 9,655 & 9,703 & 9,703 \\
\hline Sargan test & 3.25 & 2.89 & $14.25 * *$ & $12.02 * *$ & 6.33 & 5.87 \\
\hline
\end{tabular}


Table 6. Banking liberalization, economic development and firm leverage

Regressions are estimated using the Arellano and Bond (1991) two-step GMM difference estimator for panel data with lagged dependent variables. Three dependent variable are used: total, short-term, and long-term debt. The dependent variables are measured as the ratio between the book value of debt and the market value of total

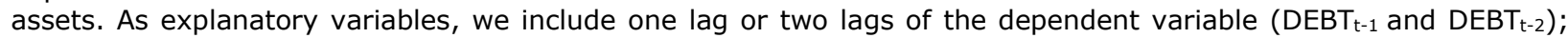
PROFIT is estimated as EBIT plus depreciation expenses and provisions (non-cash deductions from earnings) divided by total assets; GROWTH is growth opportunities and is measured by Tobin's Q. PPE is the ratio between tangible assets (property, plant and equipment) and total assets; SIZE is the natural logarithm of sales; PRBOND is the percentage of private domestic debt over GDP; CONC is the fraction of assets held by the three largest commercial banks in each country; RIGHTS measures the protection of property rights; CREDITORS measures the protection of creditor rights; ENFORCE measures the country's legal enforcement; BFREEDOM measures the openness of the banking and financial system; DEV is a dummy variable that takes a value of 1 for developed countries and 0 for developing economies. T-statistics are in parentheses. $* * *, * *$ and $*$ represent significance at the $1 \%, 5 \%$, and $10 \%$ levels, respectively.

\begin{tabular}{|c|c|c|c|c|c|c|}
\hline & \multicolumn{2}{|c|}{ Total debt } & \multicolumn{2}{|c|}{ Short-term debt } & \multicolumn{2}{|c|}{ Long-term debt } \\
\hline & $(1)$ & $(2)$ & (3) & (4) & (5) & $(6)$ \\
\hline Intercept & $\begin{array}{c}-0.0173 * * * \\
(-4.33)\end{array}$ & $\begin{array}{c}-0.0183 * * * \\
(-4.31)\end{array}$ & $\begin{array}{c}-0.0109^{* *} \\
(-2.37)\end{array}$ & $\begin{array}{c}-0.0105 * * * \\
(-2.61)\end{array}$ & $\begin{array}{c}-0.0060 * * \\
(-2.17)\end{array}$ & $\begin{array}{c}-0.0066^{* * * *} \\
(-2.78)\end{array}$ \\
\hline $\mathrm{DEBT}_{\mathrm{t}-1}$ & $\begin{array}{c}0.8269 * * * \\
(11.66)\end{array}$ & $\begin{array}{c}0.7384^{* * *} \\
(7.60)\end{array}$ & $\begin{array}{c}0.5695^{* * *} \\
(15.67)\end{array}$ & $\begin{array}{c}0.5823 * * * \\
(19.01)\end{array}$ & $\begin{array}{c}0.6753 * * * \\
(10.34)\end{array}$ & $\begin{array}{c}0.6835^{* * *} \\
(14.75)\end{array}$ \\
\hline $\mathrm{DEBT}_{\mathrm{t}-2}$ & & & $\begin{array}{c}0.0864^{* * *} * \\
(6.28)\end{array}$ & $\begin{array}{c}0.0891 * * * \\
(6.52)\end{array}$ & $\begin{array}{l}0.0024 \\
(0.15)\end{array}$ & $\begin{array}{l}0.0091 \\
(0.65)\end{array}$ \\
\hline PROFIT & $\begin{array}{l}-0.0615 \\
(-0.42)\end{array}$ & $\begin{array}{c}-0.0826 \\
(-0.37)\end{array}$ & $\begin{array}{c}-0.0584 \\
(-0.35)\end{array}$ & $\begin{array}{c}-0.1030 \\
(-0.79)\end{array}$ & $\begin{array}{l}-0.0903 \\
(-1.02)\end{array}$ & $\begin{array}{c}-0.1152^{* *} \\
(-2.00)\end{array}$ \\
\hline GROWTH & $\begin{array}{c}-0.0074 \\
(-1.51)\end{array}$ & $\begin{array}{l}-0.0091 \\
(-1.18)\end{array}$ & $\begin{array}{l}-0.0056 \\
(-0.65)\end{array}$ & $\begin{array}{c}-0.0040 \\
(-0.59)\end{array}$ & $\begin{array}{l}-0.0012 \\
(-0.69)\end{array}$ & $\begin{array}{c}-0.0018 \\
(-1.53)\end{array}$ \\
\hline PPE & $\begin{array}{c}0.3405^{* * * *} \\
(3.36)\end{array}$ & $\begin{array}{c}0.1669 \\
(1.38)\end{array}$ & $\begin{array}{c}0.0894 \\
(1.39)\end{array}$ & $\begin{array}{l}0.0415 \\
(0.74)\end{array}$ & $\begin{array}{c}0.3131 * * * \\
\quad(4.45)\end{array}$ & $\begin{array}{c}0.2336^{* * * *} \\
(3.79)\end{array}$ \\
\hline SIZE & $\begin{array}{c}0.1997 * * * \\
(4.38)\end{array}$ & $\begin{array}{c}1.1059 * * * \\
(4.21)\end{array}$ & $\begin{array}{c}0.0705^{* * *} \\
(2.64)\end{array}$ & $\begin{array}{c}0.3254 * * \\
(2.34)\end{array}$ & $\begin{array}{c}0.0825^{* *} \\
(2.36)\end{array}$ & $\begin{array}{c}0.5921 * * * \\
(3.12)\end{array}$ \\
\hline PRBOND & $\begin{array}{c}-0.0767^{*} \\
(-1.65)\end{array}$ & $\begin{array}{c}-0.1047 * * \\
(-2.61)\end{array}$ & $\begin{array}{c}-0.0241 \\
(-0.95)\end{array}$ & $\begin{array}{c}-0.0318 \\
(-1.28)\end{array}$ & $\begin{array}{c}-0.0294 \\
(-1.05)\end{array}$ & $\begin{array}{c}-0.0503^{* *} \\
(-2.07)\end{array}$ \\
\hline $\mathrm{CONC}$ & $\begin{array}{c}-0.2094 * * * \\
(-2.78)\end{array}$ & $\begin{array}{c}-0.1808 * * \\
(-2.31)\end{array}$ & $\begin{array}{l}-0.1231 \\
(-1.51)\end{array}$ & $\begin{array}{c}-0.0974 \\
(-1.61)\end{array}$ & $\begin{array}{c}-0.0265 \\
(-0.77)\end{array}$ & $\begin{array}{c}-0.0199 \\
(-0.69)\end{array}$ \\
\hline RIGHTS $x$ ENFORCE & $\begin{array}{c}-0.0026^{* * *} \\
(-4.76)\end{array}$ & $\begin{array}{c}-0.0028 * * * \\
(-3.99)\end{array}$ & $\begin{array}{c}-0.0013 * * * \\
(-2.86)\end{array}$ & $\begin{array}{c}-0.0015 * * * \\
(-3.82)\end{array}$ & $\begin{array}{c}-0.0009 * * \\
(-2.42)\end{array}$ & $\begin{array}{c}-0.0012^{* * *} \\
(-3.04)\end{array}$ \\
\hline CREDITORS $x$ ENFORCE & $\begin{array}{c}0.0003 \\
(1.11)\end{array}$ & $\begin{array}{c}0.0008 * * * \\
(2.66)\end{array}$ & $\begin{array}{c}-0.0005^{*} \\
(-1.84)\end{array}$ & $\begin{array}{c}-0.0003 \\
(-1.35)\end{array}$ & $\begin{array}{c}0.0009^{* * *} \\
(4.51)\end{array}$ & $\begin{array}{c}0.0012^{* * *} \\
(5.14)\end{array}$ \\
\hline BFREEDOM & $\begin{array}{c}0.0015^{* * * *} \\
(3.00)\end{array}$ & $\begin{array}{c}0.0044 * * * \\
(3.69)\end{array}$ & $\begin{array}{c}0.0007 * * \\
(2.05)\end{array}$ & $\begin{array}{c}0.0016^{* *} \\
(2.42)\end{array}$ & $\begin{array}{c}-0.0001 \\
(-0.34)\end{array}$ & $\begin{array}{c}0.0016^{* *} \\
(2.14)\end{array}$ \\
\hline BFREEDOM $_{\mathrm{t}-1}$ & $\begin{array}{c}-0.0023 * * * \\
(-5.86)\end{array}$ & $\begin{array}{l}0.0014 \\
(1.44)\end{array}$ & $\begin{array}{c}-0.0011 * * * \\
(-3.62)\end{array}$ & $\begin{array}{l}0.0003 \\
(0.40)\end{array}$ & $\begin{array}{c}-0.0008 * * * \\
(-2.79)\end{array}$ & $\begin{array}{l}0.0009 \\
(1.37)\end{array}$ \\
\hline BFREEDOM $_{\mathrm{t}-2}$ & $\begin{array}{c}0.0021 * * * \\
(6.14)\end{array}$ & $\begin{array}{c}0.0043 * * * \\
(7.10)\end{array}$ & $\begin{array}{c}0.0009 * * * \\
(3.38)\end{array}$ & $\begin{array}{c}0.0014 * * * \\
(3.50)\end{array}$ & $\begin{array}{c}0.0008 * * * \\
(3.07)\end{array}$ & $\begin{array}{c}0.0023 * * * \\
(4.26)\end{array}$ \\
\hline BFREEDOM x DEV & $\begin{array}{c}-0.0013 * * \\
(-2.23)\end{array}$ & $\begin{array}{c}-0.0004 \\
(-0.56)\end{array}$ & $\begin{array}{c}-0.0001 \\
(-0.36)\end{array}$ & $\begin{array}{c}0.0002 \\
(0.40)\end{array}$ & $\begin{array}{l}0.0000 \\
(0.12)\end{array}$ & $\begin{array}{l}0.0002 \\
(0.45)\end{array}$ \\
\hline BFREEDOM $_{\mathrm{t}-1}$ x DEV & $\begin{array}{l}0.0034 * * * \\
(7.55)\end{array}$ & $\begin{array}{l}0.0022 * * * \\
\quad(3.00)\end{array}$ & $\begin{array}{l}0.0012 * * * \\
(3.21)\end{array}$ & $\begin{array}{l}0.0007 \\
(1.47)\end{array}$ & $\begin{array}{l}0.0014^{* * *} \\
(4.29)\end{array}$ & $\begin{array}{l}0.0011 * * \\
(2.52)\end{array}$ \\
\hline BFREEDOM $_{\mathrm{t}-2}$ x DEV & $\begin{array}{c}-0.0020^{* *} \\
(-2.23)\end{array}$ & $\begin{array}{l}-0.0017 \\
(-1.43)\end{array}$ & $\begin{array}{l}-0.0006 \\
(-1.16)\end{array}$ & $\begin{array}{c}-0.0007^{*} \\
(-1.71)\end{array}$ & $\begin{array}{c}-0.0011^{*} \\
(-1.95)\end{array}$ & $\begin{array}{c}-0.0010^{* *} \\
(-2.12)\end{array}$ \\
\hline BFREEDOM x SIZE & & $\begin{array}{c}-0.0068 * * * \\
(-3.37)\end{array}$ & & $\begin{array}{c}-0.0020^{*} \\
(-1.90)\end{array}$ & & $\begin{array}{c}-0.0036 * * * \\
(-2.62)\end{array}$ \\
\hline BFREEDOM $_{\mathrm{t}-1} \mathrm{x}$ SIZE & & $\begin{array}{c}-0.0074 * * * \\
(-4.48)\end{array}$ & & $\begin{array}{c}-0.0028 * * * \\
(-2.67)\end{array}$ & & $\begin{array}{c}-0.0033 * * * \\
(-2.63)\end{array}$ \\
\hline BFREEDOM $_{\mathrm{t}-2}$ x SIZE & & $\begin{array}{c}-0.0075 * * * \\
(-3.64)\end{array}$ & & $\begin{array}{c}-0.0014 \\
(-1.23)\end{array}$ & & $\begin{array}{c}-0.0045^{* * *} \\
(-3.31)\end{array}$ \\
\hline BFREEDOM x SIZE x DEV & & $\begin{array}{l}0.0021 \\
(1.60)\end{array}$ & & $\begin{array}{l}0.0004 \\
(0.61)\end{array}$ & & $\begin{array}{l}0.0012^{*} \\
(1.70)\end{array}$ \\
\hline BFREEDOM $_{\mathrm{t}-1}$ x SIZE x DEV & & $\begin{array}{l}0.0027 * * * \\
(2.76)\end{array}$ & & $\begin{array}{l}0.0012 * \\
(1.94)\end{array}$ & & $\begin{array}{l}0.0007 \\
(1.04)\end{array}$ \\
\hline BFREEDOM $_{\mathrm{t}-2} \times$ SIZE $x$ DEV & & $\begin{array}{l}0.0024 * * \\
(2.23)\end{array}$ & & $\begin{array}{l}0.0004 \\
(0.53)\end{array}$ & & $\begin{array}{l}0.0018^{* *} \\
(2.32)\end{array}$ \\
\hline Country-Industry Dummies & Yes & Yes & Yes & Yes & Yes & Yes \\
\hline Industry-Year Dummies & Yes & Yes & Yes & Yes & Yes & Yes \\
\hline Country-Year Dummies & Yes & Yes & Yes & Yes & Yes & Yes \\
\hline $\mathrm{m}_{2}$ & -0.38 & -0.53 & -0.85 & -0.82 & 0.90 & 0.89 \\
\hline \# observations & 41,145 & 41,145 & 40,710 & 40,710 & 40,265 & 40,265 \\
\hline \# firms & 9,820 & 9,820 & 9,655 & 9,655 & 9,703 & 9,703 \\
\hline Sargan test & 0.38 & 0.86 & 2.29 & 3.14 & 0.97 & 0.99 \\
\hline
\end{tabular}


Appendix A. Variables

The table shows the definition of variables used in the paper and their sources

\begin{tabular}{|c|c|c|}
\hline Name & Definition & Source \\
\hline \multicolumn{3}{|c|}{ DEBT STRUCTURE } \\
\hline Total debt & $\begin{array}{l}\text { The ratio between total debt and market value of assets. The market value of assets } \\
\text { is estimated adding the market value of equity and the book value of debt. }\end{array}$ & Worldscope \\
\hline $\begin{array}{l}\text { Short-term } \\
\text { debt }\end{array}$ & $\begin{array}{l}\text { The ratio between short-term debt and market value of assets. The market value of } \\
\text { assets is estimated adding the market value of equity and the book value of debt. }\end{array}$ & Worldscope \\
\hline $\begin{array}{l}\text { Long-term } \\
\text { debt }\end{array}$ & $\begin{array}{l}\text { The ratio between long-term debt and market value of assets. The market value of } \\
\text { assets is estimated adding the market value of equity and the book value of debt. }\end{array}$ & Worldscope \\
\hline \multicolumn{3}{|c|}{ BANKING LIBERALIZATION } \\
\hline BFREEDOM & $\begin{array}{l}\text { Composite index of the extent of government regulation of financial services; the } \\
\text { extent of state intervention in banks and other financial services; the difficulty of } \\
\text { opening and operating financial services firms (for both domestic and foreign } \\
\text { individuals); and government influence on the allocation of credit. }\end{array}$ & Heritage Foundation \\
\hline \multicolumn{3}{|c|}{ OTHER COUNTRY VARIABLES } \\
\hline PRBOND & $\begin{array}{l}\text { Private domestic debt securities issued by financial institutions and corporations as a } \\
\text { percentage of GDP. }\end{array}$ & $\begin{array}{l}\text { Financial Development } \\
\text { and Structure Dataset } \\
\text { (World Bank). Beck et } \\
\text { al. (2009) }\end{array}$ \\
\hline
\end{tabular}

CONC The fraction of bank assets held by the three largest commercial banks in the country.

World Bank Database

RIGHTS Indicator of the degree to which private property rights are protected and the degree to which government enforces laws that protect private property. It also accounts for the possibility that private property may be expropriated, and analyzes the independence of the judiciary, corruption within the judiciary, and the ability of individuals and businesses to enforce contracts. It ranges between 1 and 5 . We reverse the scale of the original index, so that a high score indicates greater legal protection of property.

CREDITORS This index measures four powers of secured lenders in bankruptcy: (1) whether there are restrictions, such as creditor consent, when a debtor files for reorganization; (2) whether secured creditors are able to seize their collateral after the petition for reorganization is approved, that is, whether there is no automatic stay or asset freeze imposed by the court; (3) whether secured creditors are paid first out of the proceeds of liquidating a bankrupt firm; and (4) whether an administrator, and not management, is responsible for running the business during the reorganization. A value of one is added to the index when a country's laws and regulations provide each of these powers to secured lenders, consequently it varies between 0 (poor creditor rights) and 4 (strong creditor rights).

ENFORCE Annual index of law and order of the International Country Risk Guide (ICRG). This ranges from 0 to 6 with a higher figure indicating a better quality and enforcement of the legal system.

ICRG published by the Political Risk Service Group

OFFICIAL Official supervisory power, ranging from 0 to 16 , captures the power of supervisors to take prompt corrective action, to restructure and reorganize troubled banks, and to declare a troubled bank insolvent. Higher values indicate greater power of supervisors.

MONITOR Private oversight, ranging from 0 to 12 , measures the intensity of audit and information disclosure requirements, and whether subordinated debt is allowable as a part of regulatory capital. Higher values indicate greater private oversight.

DEV

Dummy variable that takes a value of 1 for developed countries and 0 for developing economies. Developed countries are countries classified as high income and upper middle income and developing countries are countries classified as low income and

Barth et al. (2001)

ower middle income according to GNI per capita, calculated using the World Bank's Atlas method.

\section{CONTROL VARIABLES AT FIRM LEVEL}

PROFIT Earnings before interest and taxes plus depreciation expenses and provisions (non- Worldscope cash deductions from earnings) divided by total assets

GROWTH The market-to-book ratio

Worldscope

PPE

The percentage of property, plant and equipment in total assets

Worldscope

Worldscope 


\section{Appendix B. Index of Banking Freedom}

The table describes the ten categories of the Banking and Finance Index established by the Heritage Foundation. The scale runs from 0 to 100: A higher score signifies a less restrictive banking industry. Source: 2009 Index of Economic Freedom. Heritage Foundation

\begin{tabular}{lll}
\hline \hline Score & Government influence & Criteria \\
\hline 100 & Negligible & $\begin{array}{l}\text { Independent central bank supervision and regulation of financial institutions } \\
\text { are limited to enforcing contractual obligations and preventing fraud. }\end{array}$ \\
& & Independent central bank supervision and regulation of financial institutions
\end{tabular}

\section{Nominal}

Limited

Significant

Considerable

Strong

Extensive

Heavy

Near repressive

Repressive
Independent central bank supervision and regulation of financial institutions are minimal but may extend beyond enforcing contractual obligations and preventing fraud.

Independent central bank supervision and regulation of financial institutions are minimal but may extend beyond enforcing contractual obligations and preventing fraud. Government ownership of financial institutions is a small share of overall sector assets. Financial institutions face almost no restrictions on their ability to offer financial services.

Credit allocation is slightly influenced by the government, and private allocation of credit faces almost no restrictions. Foreign financial institutions are subject to few restrictions.

The central bank is not fully independent, its supervision and regulation of financial institutions are somewhat burdensome, and its ability to enforce contracts and prevent fraud is insufficient. The government exercises active ownership and control of financial institutions with a significant share of overall sector assets. The ability of financial institutions to offer financial services is subject to some restrictions.

Credit allocation is significantly influenced by the government, and private allocation of credit faces significant barriers. The ability of financial institutions to offer financial services is subject to significant restrictions. Foreign financial institutions are subject to some restrictions.

The central bank is subject to government influence, its supervision and regulation of financial institutions are heavy, and its ability to enforce contracts and prevent fraud is weak. The government exercises active ownership and control of financial institutions with a large minority share of overall sector assets.

Credit allocation is extensively influenced by the government. The government own or controls a majority of financial institutions or is in a dominant position. Financial institutions are heavily restricted, and bank formation faces significant barriers. Foreign financial institutions are subject to significant restrictions.

The central bank is not independent, and its supervision and regulation of financial institutions are repressive. Foreign financial institutions are discouraged or highly constrained.

Credit allocation is controlled by the government. Bank formation is restricted. Foreign financial institutions are prohibited.

Supervision and regulation are designed to prevent private financial institutions. Private financial institutions are prohibited. 